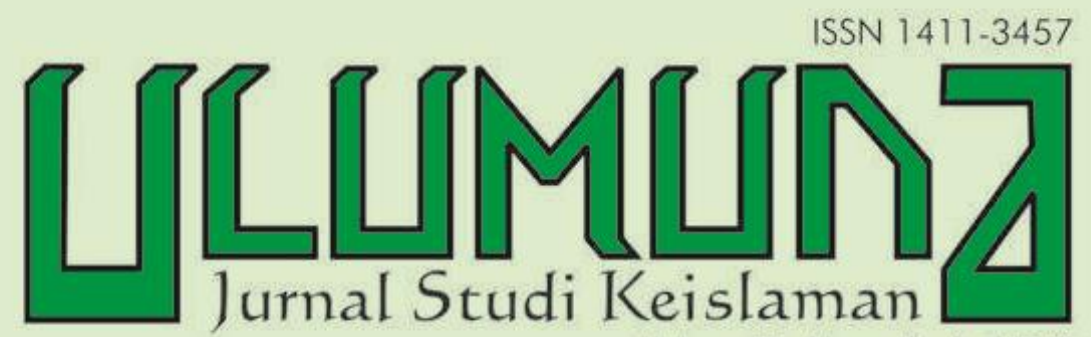

Volume $17 \cdot$ Nomor $1 \cdot$ Juni 2013

TERAKREDITASI B: SK Dirjen Dikti Kemdikbud Nomor: 56/DIKTI/Kep/2012, Tanggal 24 Juli 2012

MENCERNA AKAR FILSAFAT DALAM ISLAM Ismail Fahmi Arrauf PERKEMBANGAN PARADIGMA EPISTEMOLOGI DALAM FILSAFAT ISLAM Fathul Mufid EPISTEMOLOGI ISLAM: KEDUDUKAN WAHYU SEBAGAI SUMBER ILMU Anwar Muiahidin DARI ISLAMISASI ILMU MENUJU PENGILMUAN ISLAM: MELAWAN HEGEMONI EPISTEMOLOGI BARAT Ismail Toib dan Mukhlis INDUKTIVISME SEBAGAI BASIS PENGEMBANGAN ILMU PENGETAHUAN DALAM ISLAM Masdar Hilmy

PERTAUTAN ONTOLOGI FILSAFAT DAN TASAWUF: PERSPEKTIF TENTANG RELASI TUHAN, MANUSIA, DAN ALAM Hadarah Rajab PERTAUTAN EPISTEMOLOGI FILSAFAT DAN TASAWUF: TELAAH SISTEM PEMIKIRAN ABDUL HALIM MAHMUD Lalu Muchsin Effendi ETIKA DALAM FILSAFAT ISLAN:

PEMIKIRAN FILOSOF MUSLIM TENTANG KEBAHAGIAAN Mustain PEngembangan Sumber Daya MANusia DALAM PERSPEKTIF EPESTIMOLOGI FILSAFAT ISLAM Asep Kumiawan 


\section{DAFTAR ISI}

\section{Pedoman Transliterasi}

1-18 • Ismail Fahmi Arrauf,

"Mencerna Akar Filsafat dalam Islam"

19-40 • Fathul Mufid,

"Perkembangan Paradigma Epistemologi

dalam Filsafat Islam"

41-64 • Anwar Mujahidin

"Epistemologi Islam:

Kedudukan Wahyu Sebagai Sumber Ilmu"

65-96 • Ismail Toib dan Mukhlis

"Dari Islamisasi Ilmu Menuju Pengilmuan Islam:

Melawan Hegemoni Epistemologi Barat"

97-126 • Masdar Hilmy

"Induktivisme Sebagai Basis Pengembangan

Ilmu Pengetahuan dalam Islam"

127-152 • Hadarah Rajab

"Pertautan Ontologi Filsafat dan Tasawuf:

Telaah Relasi Tuhan, Manusia, dan Alam"

153-190 • Lalu Muchsin Effendi

"Pertautan Epistemologi Filsafat dan Tasawuf:

Telaah Sistem Pemikiran Abdul Halim Mahmud"

191-212• Mustain

"Etika dan Ajaran Moral Filsafat Islam:

Pemikiran Para Filosof Muslim tentang Kebahagiaan"

\section{3-230 • Asep Kurniawan}

Pengembangan Sumber Daya Manusia

dalam Perspektif Epestimologi Filsafat Islam

\section{APENDIKS}




\section{PEDOMAN TRANSLITERASI}

\begin{tabular}{|c|c|c|c|c|c|c|}
\hline 1 & $=$ & $\mathbf{a}$ & $\dot{\varepsilon}$ & $\dot{\varepsilon}$ & $=$ & $\mathrm{g}$ \\
\hline ب & $=$ & $\mathbf{b}$ & & ف & $=$ & $\mathbf{f}$ \\
\hline$ت$ & $=$ & $t$ & & ق & $=$ & $q$ \\
\hline$\dot{H}$ & $=$ & th & & ك5 & $=$ & $\mathbf{k}$ \\
\hline ج & $=$ & $\mathfrak{j}$ & & j & $=$ & 1 \\
\hline$\tau$ & $=$ & ḥ & & b & $=$ & $\mathbf{m}$ \\
\hline$\dot{\tau}$ & $=$ & $\mathbf{k h}$ & & ن & $=$ & $\mathbf{n}$ \\
\hline د & $=$ & d & & و & $=$ & $\mathbf{w}$ \\
\hline$\dot{j}$ & $=$ & dh & $\circ$ & ○ & $=$ & $\mathbf{h}$ \\
\hline$\jmath$ & $=$ & $\mathbf{r}$ & & $\varepsilon$ & $=$ & , \\
\hline j & $=$ & $\mathbf{z}$ & & ي & $=$ & $\mathbf{y}$ \\
\hline س & $=$ & $\mathrm{s}$ & & & & \\
\hline 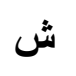 & $=$ & sh & \multicolumn{4}{|c|}{ Untuk Madd dan Diftong } \\
\hline ص - ص & $=$ & ș & i & $=$ & \multicolumn{2}{|c|}{$\bar{a}$ (a panjang) } \\
\hline ض & $=$ & d & إي اي & $=$ & \multicolumn{2}{|c|}{$\overline{1}$ (i panjang) } \\
\hline$b$ & $=$ & $\mathrm{t}$ & أو - & $=$ & \multicolumn{2}{|c|}{$\overline{\mathrm{u}}$ (u panjang) } \\
\hline ظ & $=$ & $\mathrm{z}$ & او - او & $=$ & \multicolumn{2}{|c|}{ aw } \\
\hline$\varepsilon$ & $=$ & 6 & أي & $=$ & \multicolumn{2}{|l|}{ ay } \\
\hline
\end{tabular}

Contoh penulisan dengan transliterasi:

اعوذ بالله من الشيطان الرجيم (a'üdhu bi al-Lāh min al-shaytān al-rajim);

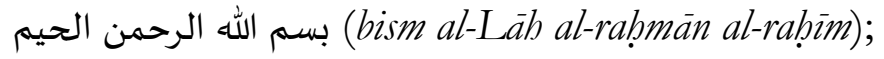

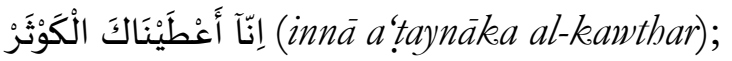

(fasalli lirabbika wanhar);

صباح الخير (șabāh al-khayr). 


\title{
PERTAUTAN EPISTEMOLOGI FILSAFAT DAN TASAWUF: TELAAH SISTEM PEMIKIRAN ABDUL HALIM MAHMUD
}

\author{
Lalu Muchsin Effendi \\ (Fakultas Tarbiyah IAIN Mataram \\ Email: fl.madjdi@yahoo.co.id)
}

Abstract: Islamic Epistemology has long been a centre of Islamic Scholars' debate. It is apparent in the discourse disputes among mutakallimuin, philosophers, and sufis as well as traditionalists versus modernists. This research hence tries to reveal Abdul Halim Mabmud's thought which analyzes Tasawuf epistemological system. Preceded by comparative studies, this research focuses on identifying the essence of Tasawnf based on Abdul Halim Mahmud's analysis. Findings of the research include Qur'an and Hadith become sources of Islamic teachings on Tasawnf epistemological system. Also, God blessing through the process of mushähadah dan mukäshafah is able to solve metaphysical problems and hence becomes a source of intuitive based knowledge.

Abstrak: Epistemologi Islam adalah perdebatan yang muncul semenjak generasi awal Islam sampai saat ini. Perselisihan yang terjadi antara para teolog (mutakallimūn), filosof dan mistikus (sufi) di satu sisi dan antara kaum tradisionalis dan modernis di sisi lain merupakan contoh diskursus ini. Penelitian ini mengungkap pemikiran Abdul Halim Mabmud yang menguraikan tentang kelebihan dan keunggulan sistem epistemologi tasawuf. Perbandingan pemikiran sebelumnya diungkap untuke mengidentifikasi esensi tasawuf. Temuan penelitian adalah sistem epistemologi tasawuf adalah sistem pengetahuan yang bersumber dari ajaran-ajaran Islam yaitu al-Qur'an dan tingkah laku Nabi Muhammad. Dengan melakukan kehidupan sufistik, hati dapat memperoleh dan memberikan pengetahuan serta mampu menyingkap berbagai persoalanpersoalan metafisis, karena ia bersumber dari karunia Tuban melalui mushāhadah dan mukāshafah.

Keywords: epistemologi, mushāhadah, mukāshafah, al-ḥikmah, irtiyāẹ, 'irfān, ishrāq, illuminasi. 
MUNGKIN tidak salah jika dikatakan bahwa wilayah yang paling kerap mendasari munculnya perbedaan antara umat Islam adalah problematika hubungan wahyu, akal dan hati. Pertanyaanpertanyaan tentang peran dan fungsi akal dihadapan wahyu, hubungan antara wahyu dan akal serta hubungan antara pengalaman spiritual dengan wahyu (syariat), agaknya menjadi pertanyaan yang selalu muncul bersama dengan munculnya aliran-aliran teologis, tasawuf dan masuknya pemikiran filsafat ke dunia Islam. Karena begitu pentingnya, sehingga menjadi kajian yang paling mashur dan mendalam dibicarakan dalam sejarah pemikiran Islam. Karenanya, tidak berlebihan jika A.J. Arberry mengatakan, "Sungguhpun telah lama menjadi bahan pembahasan, problematika akal dan wahyu tetap menarik dan segar untuk dibicarakan". ${ }^{1}$ Bahkan, menurut Harun Nasution, akan lebih hebat dan menarik lagi, jika pertemuan peradaban Barat dan umat Islam tidak terbatas hanya pada golongan tertentu (cendikiawan), tapi menjamah dan menyebar ke berbagai lapisan masyarakat secara umum. ${ }^{2}$

Munculnya pemikir-pemikir liberal di dunia Islam saat ini seperti Muḥammad Arkoun (Aljazair), Fazlur Raḥman (Pakistan), 'Alī 'Abd al-Rāziq (Mesir) Naṣr Hāmid Abū Zayd (Mesir), Hasan Hanafî (Mesir), Muḥammad 'Ābid al-Jābirī (Maroko) Muhammad Shahrūr (Siria), Nurcholis Madjid (Indonesia) dan lain sebagainya telah menjadi fenomena baru dan wacana tersendiri di kalangan gerakan intelektual Islam, karena ide-ide dan gagasan-gagasan rasional mereka seringkali dianggap menyimpang dan bertentangan dengan syariat serta ide-ide yang telah dianggap mapan. 'Alī 'Abd al-Rāziq misalkan, dipecat sebagai salah seorang guru besar di Universitas al-Azhar karena ide-idenya tentang khilafah dalam karyanya al-Islam wa Ușul al-Hukm yang dianggap mengusung faham sekular ${ }^{3}$. Fazlur t.t.), 7 .

${ }^{1}$ A. J. Arberry, Revelation and Reason in Islam (London: Allen and Unwin,

${ }^{2}$ Harun Nasution, Wabyu dan Akal dalam Islam (Jakarta: UI Press, 1982), 2.

${ }^{3}$ Menurut 'Alī 'Abd al-Rāziq, agama adalah keyakinan ruhani yang dilakukan secara individual dan sama sekali tidak ada hubungannya dengan urusan keduniaan. Karena itu, khilafah dan jihad bukanlah dari agama. 
Raḥman, karena ide-idenya dianggap menyimpang (controversial) dan sulit diterima oleh mayoritas masyarakat Pakistan terpaksa hengkang dari Pakistan ke Kanada. ${ }^{4}$ Naṣr Hāmid Abū Zayd dimurtadkan sehingga harus cerai dengan istrinya setelah beberapa karyanya divonis sesat dan keluar dari jalur-jalur Islam. ${ }^{5}$ Hasan Hanafì harus menutup jurnal al-Yasr al-Islämi (Islam Kiri)-nya karena dianggap kontroversial. ${ }^{6}$ Muhammad Shahrūr dengan bukunya al-Kitāb wa al-Qur'ān dilarang beredar di sejumlah negara seperti Mesir, Qatar, Arab Saudi, dan Kuwait karena dianggap meruntuhkan penafsiran konvensional.

Menurut Arkoun, yang menyebabkan kalangan intelektual mempersoalkan berbagai dimensi pemikiran Islam, karena mereka mengamati adanya "indoktrinasi" terhadap khazanah warisan keilmuan klasik. Al-Qur'an yang semula bersifat terbuka, polyinterpretable berubah menjadi tertutup, final, dan kaku. ${ }^{7}$ Fazlur

Agama dan dunia adalah dua hal yang berbeda dan tidak mungkin akan bertemu. 'Alī 'Abd al-Rāziq, Islàm wa Ușul al-Hukem (Kairo: al-Hay'āt al'Āmmah li al-Kitāb, t.t.), 64-70.

${ }^{4}$ Fazlur Rahman, Some Islamic Issue In the Ayub Khan Era, dalam Essays on Islamic Civilization, ed. Donald P. Little (Leiden: E. J. Brill, 1976), 299.

5Pengkafiran ini bermula dari tuduhan sejumlah pihak terhadap Nașr Ḥāmid Abū Zayd, di antaranya, Muhammad Baltàjīi Hasan, guru besar ilmu fikih dan ushul fikih serta Dekan Fakultas Sharì’ah Dār al-'Ulūm Kairo yang menilai bahwa karya Abū Zayd al-Imām al-Shäfí̀ wa al-Ta'sis al-Aydülüjizyah alWasatiyyah telah memusuhi secara kuat teks-teks agama (al-Qur'an dan Sunah) karenanya, ia menghimbau masyarakat untuk berpura-pura bodoh demi mengabaikannya. Karya ini dianggap kebodohan, karena ditulis oleh seorang yang bukan ahlinya. Ismāôi Salīm 'Abd al-'Ālì menilai karya Abū Zayd Mafbüm al-Nas;; Diräsät fì 'Ulüm al-Qur'ān sebagian besar isinya telah keluar dari norma-norma Islam. Konsensus (ijmāa para qäḍ̄ dan fuqabā untuk memurtadkan Abū Zayd dengan alasan dia telah keluar dari Islam karena dia hanya mengakui bahwa al-Qur'an hanya diturunkan bagi orang Arab, dan perkataannya bahwa syariat tidak selaras atau cocok dengan abad ini. Lihat, 'Áridah Da'wāa al-Tafríq bayn Abū Zayd wa Zawjatih, dalam al-Qähirah (Februari, 1996).

'Lihat, "Pengantar Penerbit" dalam Kazuko Shimogaki, Kiri Islam antara Modernisme dan Postmodernisme: Telaah Kritis Pemikiran Hassan Hanafi, ter. M. Imam Aziz dan M. Jadul Maula (Yogyakarta: LKiS, 1993).

${ }^{7}$ Muhạmmad Arkoun, Al-Isläm: Al-Akbläq wa al-Siyāsah, ter. Hishām Șālih (Bayrūt: Markaz al-Inmā' al-Qawmī, 1990), 182; dan Tärìkh al-Fiker al'Arabì al-Islämì (Bayrūt: Markaz al-Inmā' al-Qawmī, 1986), 17. 
Rahman mengklaim bahwa umat Islam cenderung mengabaikan pola-pola pemikiran kritis, karena kenyataannya, telah terjadi kegersangan pemikiran dalam hukum dan teologi Islam, serta ketidakselarasan berbagai praktik keagamaan semisal sufisme, khususnya dalam matrik panteisme-nya dengan al-Qur'an dan Sunnah. ${ }^{8}$

Muhammad Shahrūr mensinyalir bahwa salah satu kesalahan besar yang terdapat dalam pemikiran Islam dewasa ini, fanatisme terhadap berbagai ajaran klasik yang subjektif dan otoriter. Kajian-kajian keislaman yang ada sering kali bertolak dari perspektif lama yang dianggap sudah mapan. Kajian-kajian ini menurutnya, tidak dapat menghasilkan sesuatu yang baru, melainkan untuk memperkuat asumsi yang dianut. ${ }^{9}$

Melihat apa yang ditunjukkan oleh para sarjana di atas, dapat dikatakan bahwa sumber kritisisme atas kegelisahan intelektual mereka memiliki akar dan bertumpu pada persoalan epistemologis (teori pengetahuan). Persoalan yang dipersepsikan dalam terma metodologi ini, pada dasarnya memang menjadi poros bagi tumbuhnya wacana-wacana pembaharuan dan modernitas di dunia Islam, sekaligus menjadi lahan yang subur bagi timbulnya aliran-aliran keagamaan dalam Islam. ${ }^{10}$

\section{Epistemologi Islam; Suatu Landasan Teoretis}

Dalam Epistemologi Islam, ada beberapa jalan atau cara memperoleh pengetahuan atau yang disebut dengan sumbersumber pengetahuan yakni melalui indera, teks-teks keagamaan (wahyu), akal, dan hati. Cara pertama dilakukan dengan pengamatan inderawi terhadap hal-hal yang bersifat materi yang

${ }^{8}$ Fazlur Rahman, Islam \& Modernity: Transformation an Intellectual Tradition (Chicago: The University of Chicago, 1984), 22-8.

${ }^{9}$ Muhammad Shahrūr, al-Kitāb wa al-Qur'ān: Qiräah Mu'ạsirah (Kairo: Ibn Sīnā li al-Nashr, 1993), 30-2.

${ }^{10}$ Lihat, misalnya, perbedaan yang terjadi antara kelompok keagamaan dalam Islam seperti Mu’tazilah, 'Ash'ariyyah dan Maturidiyah yang dibangun atas dasar perbedaan pemahaman tentang peran, fungsi dan kedudukan wahyu dan akal. Begitu juga dengan pengelompokan pemikiran Islam modern menjadi tradisionalis, moderat, dan liberal. Lihat, Ali Rahnema (ed.), Para Perintis Zaman Baru Islam, ter. Ilyas Hasan (Bandung: Mizan, 1996), 10-6. 
dilakukan dengan metode observasi atau eksperimen. ${ }^{11}$ Cara kedua (wahyu) merupakan bentuk komunikasi Tuhan kepada manusia dengan perantara malaikat dan manusia yang telah dipilih Tuhan sebagai utusan-Nya (Nabi). Cara ketiga melalui akal yang dianugerahkan Tuhan kepada manusia dengan memakai kesan-kesan yang diperoleh panca indera sebagai bahan pemikiran untuk sampai kepada kesimpulan-kesimpulan tertentu. Cara keempat melalui hati atau pengalaman batin yang disebut dengan 'irfän. ${ }^{12}$

Menurut Harun, akal sebagai daya berpikir yang ada dalam diri manusia berusaha keras untuk sampai kepada Tuhan, sedangkan wahyu sebagai media informasi dari alam metafisis turun kepada manusia dengan keterangan-keterangan tentang Tuhan dan kewajiban-kewajiban manusia terhadap Tuhan. ${ }^{13}$ Hati, melalui olah rasa (riyādah), mujāhadah dan pensucian diri (tazkiyah al-nafs) yang kontinu diyakini dapat menyingkapi berbagai pengetahuan metafisis.

Pada hakikatnya, semua aliran dalam filsafat Islam, ilmu kalam ataupun tasawuf berpegang pada wahyu, dan meyakini akan kebenaran mutlaknya, hanya saja, perbedaan yang terjadi antara kelompok-kelompok ini adalah perbedaan dalam interpretasi mengenai teks ayat-ayat al-Qur'an dan hadis, dan seberapa besar mereka memberikan peran kepada akal dan hati dalam memahami teks-teks tersebut. Perbedaan-perbedaan interpretasi yang demikian ini sebenarnya terdapat juga dalam hukum Islam atau fikih yang telah melahirkan mazhab-mazhab yang kita kenal sekarang, seperti mazhab Hanafī, Mālikī, Shāfi'ī dan Hanbalī. ${ }^{14}$

${ }^{11}$ Mulyadi Kartanegara, Menyibak. Tirai Kejahilan: Pengantar Epistemologi Islam (Bandung: Mizan, 2003), 52.

12Sari Nusaibah, "Epistemologi”, dalam History of Islamic Philosophy, vol. 2, eds. Seyyed Hossein Nasr and Oliver Leaman (London: Routledge, 1996), 826.

${ }^{13}$ Harun Nasution, Akal dan Wabyu dalam Islam (Jakarta: UI Press, 1986), 1.

${ }^{14}$ Harun Nasution, Teologi Islam Aliran-aliran Sejarah Analisa Perbandingan (Jakarta: UI Press, 1986), 150. 


\section{Epistemologi Islam dalam Perdebatan}

Pembahasan tentang kedudukan akal, wahyu, dan hati terutama tentang peran dan fungsinya mempunyai sejarah yang sangat panjang terutama di kalangan kaum teolog, sufi dan filosof semenjak kemunculan golongan Mu'tazilah dan diterjemahkannya filsafat Yunani ke dunia Islam dalam permasalahan yang terkait dengan filsafat ketuhanan dan metafisika ( $m \bar{a}$ warä al-tabìah). Perbedaan pendapat tentang kedudukan akal dihadapan wahyu dan sejauh mana akal dapat memahami hal-hal yang gaib (metafisis) memunculkan polemik yang panjang antara kelompok 'Ash'ariyyah dan Mu'tazilah di satu sisi, di sisi lainnya antara kelompok 'Ash'ariyyah dengan para filosof. Pertentangan ini oleh sebagian sarjana dikategorikan sebagai pertentangan antara kaum tradisionalis yang berpegang kepada tradisi yang berasal dari sebuah otoritas eksternal yang diyakini bersifat kontinu dan stabil dengan kaum rasionalis ('Aqliyyūn) yang mempercayai kemampuan akal dalam memahami masalah-masalah metafisika yang merupakan usahausaha perorangan dan tidak tunduk pada otoritas eksternal, dan ini, biasanya menyebabkan terjadinya perubahan dan instabilitas. ${ }^{15}$

Polemik dan ketegangan antara kaum tradisionalis dan kaum rasionalis juga terjadi meminjam istilah Arkoun karena adanya "Taqdìs afkèrr al-dìn’" (sakralisasi pemikiran keagamaan) dimana para pendukungnya ingin mempertahankan khazanah intelektual lama, meskipun sudah out of date, sedang di lain pihak, orang juga ingin mengembangkan yang baru yang sesuai dengan kebutuhan dan perkembangan zaman (kontekstual). ${ }^{16}$

Perdebatan tentang peran dan fungsi wahyu, akal, dan hati telah melahirkan tokoh-tokoh ternama dan karya-karya besar berkaitan dengan permasalahan ketuhanan dan metafisika. Tạ̣ăfut al-Falāsifah (Kerancuan para Filosof) karya al-Gazālī dan

15Benyamin Abrahamov, Ilmu Kalam; Tradisionalisme dan Rasionalisme dalam Teologi Islam, ter. Nuruddin Hidayat (Jakarta: Serambi Ilmu Semesta, 2002), 9.

${ }^{16}$ Muḥammad Arkoun, Al-Isläm: al-Akhlāq wa al-Siyāsah, ter. Hishām Ṣālih (Bayrūt: Markaz Inmā’ al-Qawmī, 1990), 182; Muhammad Arkoun, Tärikeh al-Fiker al-'Arabì al-Islāmì (Beirūt: Markaz Inmā’ al-Qawmī, 1986), 17. 
sanggahannya Tạ̣āfut al-Tạ̣āfut (Kerancuan Kitab Taḥäfut) karya Ibn Rushd misalnya, merupakan salah satu bukti kuat adanya kontinuitas dan kegairahan intlektual dalam Islam yang dibangun dari perbedaan sudut pandang (paradigma) tentang otoritas wahyu dan akal.

Kritik al-Gazālī terhadap para filosof terutama dalam karyanya Tahäfut al-Faläsifah mempunyai dampak negatif terhadap perkembangan filsafat dan gerakan rasional di kalangan umat Islam. Menurut Ibrāhīm Madkūr, serangan al-Gazāīi terhadap para filosof meninggalkan akibat yang menghambat perjalanan kajian keilmuan dalam Islam, bahkan sebagian generasi yang datang belakangan berusaha menolak kajian-kajian rasional secara ekstrem. ${ }^{17}$

Ibn Rushd, sebagai seorang filosof merasa berkewajiban untuk membela akal dan para filosof walaupun dalam beberapa masalah ia tidak sepakat dengan mereka. Karyanya Tạăfut alTặäfut dan Fașl al-Maqäl fì mä Bayn al-Hikmah wa al-Sharīah min al-Ittișāl merupakan karya yang memang ditujukan untuk membahas hubungan antara filsafat dan agama. Ibn Rushd dengan teori "Kebenaran ganda" berusaha menjelaskan bahwa sebenarnya antara agama dan filsafat tidak bertentangan. Menurutnya, akal dan agama tidak menentang satu sama lainnya karena keduanya merupakan cara yang berbeda dalam menjelaskan hal yang sama. Akal merupakan penghampiran demonstratif pada realitas yang mampu menguraikan dan mengungkap realitas tersebut dalam makna yang gamblang. Sementara itu, agama menyajikan versi realitas yang sama dengan cara yang berbeda supaya dapat diterima oleh masyarakat. ${ }^{18}$

Namun, kritik al-Gazālī begitu kuatnya mengakar dalam dunia Islam, bahkan kritik Ibn Rushd pun terhadap al-Gazālī tidak cukup kuat untuk menahan laju perkembangan faham tradisionalis, sementara teologi rasional Mu'tazilah seakan

${ }^{17 L i h a t, ~ I b r a ̄ h i ̄ m ~ M a d k u ̄ r, ~ F i ̀ ~ a l-F a l s a f a h ~ a l-I s l a ̄ m i y y a h ~ M a n h a j u h u ~ w a ~}$ Taţiquhu (Kairo: Dār al-Ma‘ārif, t.t.), 21.

${ }^{18 L}$ Lihat Ibn Rushd, Faṣl al-Maqäl fì mā Bayn al-Hik-mah wa al-Shariah min al-Ittisāal (Kairo: Dār al-Ma'ārif, t.t.), 31-2. Lihat, Oliver Leaman, Pengantar Filsafat Islam: Sebuah Pendekatan Tematis, ter. Musa Kazhim dan Arif Mulyadi (Bandung: Mizan, 2001), 166. 
tenggelam dalam kebesaran teologi 'Ash'ariyyah. Namun perkembangan pemikiran rasional (filsafat) masih tetap mendapatkan momentumnya di dunia Barat terutama di Andalusia dan Iran, bahkan kemudian diperluas dan mengkristal dalam mazhab yang dikenal dengan mazhab illuminasi (ishräqi) dan mazhab Ișfahan. ${ }^{19}$

Sejalan dengan kemajuan ilmu pengetahuan dan teknologi modern yang bercirikan rasionalisme, apalagi jika dihubungkan dengan kekalahan dan kemunduran umat Islam dalam arena politik dan ekonomi. Bangsa-bangsa Eropa yang menganut rasioinalisme setelah masa pencerahan terus menerus mengalami kemajuan dalam berbagai bidang seperti ekonomi dan militer. Sedangkan umat Islam makin terpuruk akibat konflik intern yang berkepanjangan dan kolonialisasi bangsa-bangsa Eropa. Kondisi ini dikatakan oleh Cantwell Smith sebagai kondisi ketidakberdayaan umat Islam terhadap Barat. Smith mengatakan bahwa bila dalam hubungan Barat dan Timur pada abad-abad sebelumnya berada di pihak yang kuat, maka pada abad modern ini seakan-akan memperlihatkan Islam sebagai sesuatu yang tidak berdaya dan penerima pasif dari segala pengaruh yang datang dari Barat. ${ }^{20}$

Bahkan sebagian pemikir muslim terlihat seakan mengaitkan kemunduran kaum muslimin pada era modern dengan corak teologi dan tasawuf yang berkembang saat itu di dunia Islam. Aḥmad Amīn (w. 1954 M) misalnya, mengeluhkan punahnya aliran Mu'tazilah sebagai kemalangan Islam yang tak dapat diraih kembali. Ia mengatakan, "Andaikan pemikiran rasional Mu'tazilah tetap berkembang, niscaya sejarah kaum muslimin akan menjadi lain. ${ }^{21}$ Pernyataan seperti ini memang menarik

${ }^{19}$ Mazhab illuminasi yang dikembangkan oleh Suhrāwardī merupakan suatu fase pengembangan filsafat Ibn Sīnā di satu sisi, dan filsafat Plato di sisi lain. Di samping itu illuminasionis Suhrāwardī merujuk kepada Hermes dan tokoh-tokoh Yunani dan Persia Kuno. Ibrāhīm Hilāl, al-Tasawwuf alIslàmi Bayn al-Dìn wa al-Falsafah (Kairo: Dār al-Nahḍah al-'Arabiyyah, 1979), 114.

${ }^{20}$ Wilfred Cantwell Smith, Islam in Modern History (New Jersy: Princeton University Press, 1957), 14.

${ }^{21}$ Aḥmad Amīn, Zubr al-Islām, jilid IV (Beirūt: Dār al-Kitāb al-'Arabī, 1969), 39. Sekalipun Ạmad Amīn tidak secara langsung menunjuk teologi 
untuk direnungkan, terutama bila diingat bahwa kejayaan yang dicapai dunia Islam pada masa Abasiyah terjadi ketika pemikiran rasional dalam bentuk filsafat berkembang di dunia Islam, sedangkan kemunduran yang mereka alami terjadi ketika filsafat dan pemikiran rasional ditinggalkan.

Muḥammad Abduh mencoba membangkitkan kembali tradisi rasional yang menurut Harun Nasution, banyak dipengaruhi oleh pemikiran-pemikiran Mu'tazilah, walaupun Muhammad Abduh sendiri tidak pernah menyebut dan tidak mau disebut sebagai Mu'tazili (penganut faham Mu'tazilah). ${ }^{22}$ Menurut Muhammad 'Abduh, kemunduran umat Islam, disebabkan karena umat Islam telah menghilangkan tradisi keilmuan yang rasional dan kritis. Tradisi ini digantikan dengan taqlid dan sifat fatalis (jabariyyah), sehingga kemudian melahirkan fase kejumudan (stagnasi). ${ }^{23}$ Dengan alasan inilah, Muhammad 'Abduh ingin mengembalikan tradisi Islam yang telah hilang dan mengobarkan revolusi intlektual dengan menumbuhkan kajiankajian rasional yang bertumpu pada keyakinan akan kemampuan akal dalam memahami ajaran-ajaran agama.

'Ash'ariyyah sebagai penyebab mundurnya umat Islam, namun dari pernyataan di atas diperoleh kesan bahwa teologi Asy'ariyyah ikut bertanggung jawab terhadap segala kemunduran yang dialami kaum muslimin.

${ }^{22}$ Muhmmad 'Abduh pernah ditanya oleh shekh 'Alaish, salah seorang ulama al-Azhar yang menentang faham Mu'tazilah, apakah benar ia memilih aliran Mu'tazilah dan meninggalkan aliran 'Ash'ariyyah? Ia menjawab, "Jika aku meninggalkan taqlíd kepada 'Ash'ariyyah, mengapa aku mesti taqlid kepada Mu'tazilah? Aku tidak mau ber-taqlid kepada siapa pun, yang aku utamakan adalah argument yang kuat". Lihat, Muhammad Rashīd Riḍā, Tārikh Ustādh al-Imām Shekh Muḅammad 'Abduh, jilid I (Kairo: al-Mannār, 1931), 134.

${ }^{23}$ Muhammad 'Imārah, Al-A'māl al-Kämilāt li Muḅammad 'Abduh, jilid 3 (Bayrūt: al-Mu'assasah al-'Arabiyyah li al-Dirāsah wa al-Nashr, 1973), 229. Namun 'Abd al-'Ālì berpendapat bahwa kemunduran umat Islam bukan hanya disebabkan oleh tradisi taqlid, namun juga disebabkan oleh perpecahan internal umat Islam, terpecahnya daerah keekuasaan Islam menjadi negara-negara kecil yang bertikai demi membela suku dan kesetiaan kepada pemimpin mereka. Lihat, 'Abd al-'Ālī Muḥammad Aḥmad, Al-Fiker al-Siyāsì li al-Imām Muḅammad 'Abduh (Kairo: al-Hay’ah al-Mișriyyah li alKitāb, 1978), 258. 
Pembaharuan yang dilakukan oleh Muḥammad 'Abduh di Mesir adalah babak baru bagi munculnya kajian-kajian rasional dalam berbagai bidang, baik fikih, tafsir, filsafat maupun teologi. Pertemuan dengan peradaban Barat yang menganut faham rasionalisme juga turut menggerakkan umat Islam untuk menghidupkan kembali filsafat Islam dan ilmu kalam sehingga interpretasi rasional atas ajaran Islam menjadi kecenderungan yang umum dikalangan beberapa pemikir Mesir. ${ }^{24}$ Upaya Muhammad 'Abduh untuk mendorong ulama dengan gagasan modern, pada akhirnya melahirkan para cendikiawan yang muncul dengan gagasan-gagasan baru yang mencoba merespons modernitas dengan segala aspeknya. Bahkan ada yang melihat bahwa visi Muhammad 'Abduh adalah satu-satunya jawaban untuk menyelamatkan masyarakat Mesir dari ketertinggalan dari bangsa-bangsa lain, terutama bangsa Eropa. Namun demikian, ada juga yang melihat bahwa rasionalisasi yang dilakukan Muhammad 'Abduh terhadap ajaran-ajaran Islam, terutama yang terkait dengan masalah akidah dapat membahayakan keyakinan umat Islam dan membangunkan kembali perdebatan-perdebatan filosofis dan teologis yang telah mengakibatkan perpecahan di kalangan umat Islam. Karena itu, kajian-kajian filsafat dan teologis, terutama teologi Mu'tazilah mendapatkan tantangan dari beberapa ulama Mesir yang menganggap filsafat dan ilmu kalam tidak mampu untuk mengungkap realitas-realitas yang bersifat metafisis ( mà warà' al-țabìah).

Hal yang sama juga terjadi dalam dimensi esoterik Islam (tasawuf) menyangkut eksistensinya dan hubungan antara akal dan pengalaman spiritual, serta kaitan antara makna batin yang disebut dengan haqiqah dan makna lahir yang disebut dengan shariah. Bahkan tidak jarang timbul penolakan terhadap tasawuf oleh sekelompok umat Islam karena dianggap menyimpang dari ajaran Islam, terutama tentang konsep-konsep fan $\bar{a}$, ḅulül, ittiḥa d dan waḥdah al-wujūd. Penolakan terhadap sufisme menurut

${ }^{24}$ Gerakan pembaharuan Jamāl al-Dīn al-Afgānī dan Muḥammad 'Abduh memberikan kontribusi dan dorongan diterimanya kurikulim atau mata kuliah filsafat dan teologi bagi mahasiswa di beberapa universitas di Mesir seperti di Universitas Kairo dan al-Azhar. Harun Nasution, Muhammad Abduh dan Teologi Rasional Mu'tazilah (Jakarta: UI Press, 1987), 18. 
Elizabeth Siriyyeh dalam karyanya Sufis and Anti-Sufis bukanlah suatu fenomena baru yang muncul pada abad modern. Penolakan tersebut telah lama muncul dalam sejarah Islam dan mencapai puncaknya pertama kali pada penyiksaan dan eksekusi atas diri al-Hallaj, seorang sufi ekstatik karena faham ḅulül-nya sekitar tahun 922 M. ${ }^{25}$

Penolakan terhadap status eksistensi tasawuf, terutama dari kalangan ulama-ulama Sunni karena dianggap sebagai sesuatu yang tidak mempunyai dasar baik dari al-Qur'an maupun hadis. Bahkan, konsep-konsep ma'rifat yang dikembangkan oleh para sufi dianggap telah tercemari oleh konsep-konsep asing, terutama filsafat Yunani. Belum lagi kemudian, seperti yang diungkapkan oleh Elizabeth Sirriyyeh munculnya tarekat-tarekat sufi yang banyak melakukan bid'ah dan penyelewengan dari ajaran ortodoksi. ${ }^{26}$ Bahkan, secara khusus A.J. Arberry dengan keras menyerang manifestasi-manifestasi sufisme belakangan, khususnya yang terjadi pada abad XVIII dan XIX di Mesir. Dia menggambarkan sufisme sebagai bentuk pelanggaran yang luar biasa terhadap syariat dan bentuk penipuan terhadap masyarakat. ${ }^{27}$

Muhammad 'Abduh sebagai seorang pembaharu menentang keras apa yang dipandangnya sebagai manifestasi-manifestasi sufisme yang sesat di Mesir pada akhir abad ke XIX. Ia meyakini bahwa sufisme yang dipraktikkan pada zamannya itu telah menyimpang jauh dari agama Islam yang otentik. Dalam alWaqäi' al-Misriyyah ia melancarkan kritik terbuka kepada tarekattarekat sufi tertentu karena telah bersalah memperkenalkan bid'ah-bid'ah yang berperan dalam kemerosotan masyarakat. ${ }^{28}$

${ }^{25}$ Elizabeth Sirriyeh, Sufi dan Anti-Sufi, ter. Ade Alimah (Jogyakarta: Pustaka Sufi, 2003), xv. Lihat juga, Annemarie Schimmel, Dimensi Mistik dalam Islam, ter. Supardi Djoko Purnomo (Jakarta: Pustaka Firdaus, 2000), 85.

26. Sirriyeh, Sufis and..., 34-5.

${ }^{27}$ A. J. Arberry, Sufism: An Account of the Mystic of Islam (London: George Allen and Unwin, 1950).

${ }^{28}$ Ekspresi Muhammad 'Abduh dituangkan dalam sebuah artikel pada 30 November 1880. Dalam artikel ini, ia juga mendukung usaha untuk melarang beberapa praktik sufi yang dilakukan di Masjid Imām al-Husayn dan Sayyidah Zaynab. 
Di sisi lain, pembaharuan dan pemurnian agama (purifikasi) yang dilakukan oleh kaum Wahabi di Makkah pada abad ke XVIII yang kemudian disusul dengan munculnya gerakan, atau upaya pembaharuan pemikiran keagamaan di dunia Islam memberikan pengaruh terhadap kemunduran tasawuf. Gerakan Wahabi yang muncul sebagai reaksi terhadap pengamalan syariat Islam, jelas-jelas menentang praktik dan ritual yang dilakukan oleh sekelompok aliran tasawuf yang mereka pandang bid'ah dan bercampur khurafat. ${ }^{29}$

Berbeda dengan upaya pembaharuan di dunia Islam, terutama di Mesir, yang dimotori oleh Jamāl al-Dīn al-Afgān̄̄ dan Muhammad 'Abduh lebih dirangsang oleh kemunduran dan keterbelakangan umat Islam dari negara-negara Eropa. Dengan demikian, pembaharuan pemikiran Islam di Mesir, masalahnya bukan terbatas pada permunian kembali ajaran-ajaran Islam, tapi juga, dan yang utama, bagimana memodernisasi dan memajukan umat Islam serta mengejar ketertinggalan dari peradaban dunia Barat yang modern? Pemurnian pemahaman syariat bagi kaum modernis dan reformis hanya merupakan langkah awal dan syarat mutlak bagi pengembangan pemikiran lebih lanjut. Maka, yang menjadi pokok masalah bagi para pembaharu ini adalah, bagaimana membuat paradigma berpikir masyarakat Islam agar bisa menguasai ilmu pengetahuan modern dan teknologi seperti halnya bangsa Barat. Karena ilmu pengetahuan dan teknologi menjadi idaman para pembaharu pemikiran Islam, maka, aspek rasional dan penalaran yang kritis merupakan sendi dan dasar bagi pengembangan pemikiran ilmiah. Bahkan, boleh dikatakan sejak awal kebangkitan pemikiran Islam, telah nampak pemikiran rasional Mu'tazilah dan para filosof dalam diri seorang ulama besar dalam pembaharuan di dunia Islam yaitu Muḥammad 'Abduh. ${ }^{30}$

${ }^{29}$ Natana J. Delong Bas, Wababi Islam From Revival and Reform to Global Jihad (London: Oxford University Press, 2004 ), 41.

${ }^{30}$ Harun Nasution, dalam penelitiannya tentang corak pemikiran Muhammad 'Abduh sampai pada suatu kesimpulan bahwa corak pemikiran Muhammad 'Abduh banyak dipengaruhi oleh pemikiran-pemikiran rasional Mu'tazilah. Lihat, Harun Nasution, Muhammad Abduh dan Teologi Rasional Mu'tazilah (Jakarta: Universitas Indonesia, 1989). 
Gerakan pembaharuan pemikiran dalam Islam ini, langsung maupun tidak langsung, juga menyudutkan ajaran tasawuf dan berbagai aliran tarekatnya, yang menurut mereka sebagai penghalang dan penyebab kemunduran umat Islam. Pembaharuan di Turki misalnya, melarang praktik tarekat karena dianggap atau dinilai sebagai penyebab kemunduran dan kebodohan umat. ${ }^{31}$

\section{'Abd al Halīm Mạ̣mūd dan Masalah Sumber Pengetahuan}

'Abd al Halīm Maḥmūd (selanjutnya disingkat AHM) adalah salah seorang pemikir penting dalam sejarah pemikiran Islam di Mesir dan mantan Shaykh Azhar yang juga meraih gelar doktor dalam bidang studi Islam pada Universitas Sorbon di Perancis. Ia dikenal sebagai tokoh yang sangat vokal dan banyak mengkritik paham-paham keagamaan yang berkembang pada masanya, sehingga ia dikenal sebagai "Gazālī Mesir", di samping dikenal di kalangan para sufi Mesir sebagai "Abū al-'Ārifīn". 32

AHM, dilahirkan tahun $1910 \mathrm{M}$, yakni lima tahun setelah meninggalnya Muhammad 'Abduh, tentu sangat mengenal gerakan yang dilakukan oleh Muhammad 'Abduh dan para muridnya, namun AHM termasuk sarjana lulusan universitas Barat yang cenderung berpikir tradisional, karena melihat modernisasi yang bercirikan rasionalisme dan sekularisme sebagai proses yang dapat menghancurkan struktur masyarakat Arab dan nilai-nilai klasik yang mulia. ${ }^{33}$

Ada berbagai komentar tentang intelektualitas AHM. Hasan Hanafí, seorang cendikiawan kontemporer Mesir, misalnya, ketika memberikan kata pengantar pada buku Islam Garda Depan Mozaik Pemikiran Islam Timur Tengah menggolongkannya sebagai ulama yang berpikir tekstualis atau lebih sebagai pemikir

${ }^{31}$ Ira M. Lapidus, A History of Islamic Societies (Cambridge: Cambridge University Press, 2002), 501-2.

${ }^{32}$ Gelar ini diungkapkan oleh Shaykh Muhammad Zakī Ibrāhīm ketika memberikan kesan akhir dari cetakan ke lima pada karya Abdul Halim Mahmud, Qadiyyah al-Tasawnuf al-Munqidh min al Daläl. Lihat, Abdul Halim Mahmud, Qadiyyah al-Tașawwu al-Munqidh min al-Ḍalāl (Kairo: Dār al-Ma’ārif, 1998), 401.

${ }^{33}$ Lihat, Ra'ūf Shalabī, Al-Imām al-Akbar Shekh al-Islàm 'Abd al-Halìm Mạ̣mūd, (Kuwait: Dār al-Qalam, 1983), 24. 
tradisionalis konservatif. ${ }^{34}$ Namun Hasan Hanafī tidak menerangkan lebih jauh, apakah AHM termasuk kelompok tradisionalis beraliran 'Ash'ariyyah, Maturidiyyah ataukah Salafiyyah. Hasan Hanafī juga menggolongkan AHM sebagai seorang mutakallim yang pemikiran filsafat dan teologisnya banyak dipengaruhi oleh konsep-konsep tasawufnya al-Muhāāibī dan al-Gazālī. Ra'ūf Shalabī dalam karyannya Shaykeh al-Islām 'Abd al-Halim Mahmüd dengan lebih jelas mengatakan bahwa AHM menganut paham Salafi, yaitu paham yang mengajak kembali kepada konsep ittibä' atau mengikuti al-Qur'an, sunah dan praktik-praktik keagamaan para sahabat dan tabi'in. ${ }^{35}$ Sebaliknya, Abdullah Schleifer dalam tulisannya tentang Tasawuf di Mesir dan Timur Arab menganggap AHM sebagai tokoh penting dalam kebangkitan tasawuf di kalangan masyarakat terdidik Mesir dengan membangkitkan kembali studi tasawuf dengan bahasa yang lebih populer. ${ }^{36}$ Sayyed Hossien Nasr dalam pendahuluannya tentang tasawuf di dunia Islam modern menganggapnya sebagai seorang sufi sekaligus filosof Islam yang banyak menulis dalam kedua bidang ini. ${ }^{37}$ Sedangkan Massimo Campanini menganggap sebagai seorang filosof illuminatif yang berusaha memadukan antara pengetahuan sufistik dan pengetahuan filosofis. ${ }^{38}$

Menurut Abdullah Schleifer, seorang peneliti tentang Tasawuf kontemporer di Mesir pada Universitas Amerika di Kairo, AHM merupakan tokoh yang paling penting dalam kebangkitan kembali tasawuf dikalangan kelas terdidik Mesir dengan menerbitkan lusinan buku yang memperkenalkan kembali kepada masyarakat Mesir tokoh-tokoh pencerah spiritual dalam ilmu tasawuf seperti Dhūn al-Nūn al-Mișrī, alḤāris bin Asad al-Muhāāibī, Abū Hạan al-Shādhilī, 'Abdullāh

${ }^{34}$ M. Aunul Abid Syah dkk., Islam Garda Depan Mosaik Pemikiran Islam Timur Tengah (Bandung: Mizan, 2001), 11.

35Shalabī, Shaykh al-Isläm..., 21.

${ }^{36}$ Abdullah Schleifer, Tasawnf di Mesir dan Timur Arab dalam Ensiklopedi Tematis Spiritual Islam Manifestasi, ed. Seyyed Hossien Nasr, ter. M. Solihin Arianto dkk., (Bandung: Mizan, 2003), 271.

${ }^{37} \mathrm{Nasr}$, Intoduction to The Mistical..., 371.

${ }^{38}$ Campanini, History of Islamic..., 1119. 
bin Mubārak dan lain-lain. Karya-karya ini lebih dari sekedar penegasan kembali doktrin-doktrin sufi dalam bahasa kontemporer dan popular. ${ }^{39}$ Namun, karya-karya tersebut mengembalikan kepada masyarakat Mesir pemahaman dan pengetahuan yang sempat menghilang tentang pesan-pesan spiritual yang mendalam yang diungkapkan oleh tokoh-tokoh tersebut dan terkandung dalam ajaran para sufi. Pesan-pesan yang sebagian besar orang Mesir telah tertutup oleh pandangan popular tentang para wali yang hanya berperan sebagai pemberi syafaat dan hidup menyendiri. AHM juga berupaya menjembatani jurang artificial tentang tasawuf yang telah berkembang sejak abad ke XII H/XIX M, yang memisahkan antara ilmu dan ma'rifat, syariat dan hakikat, lahir dan batin serta pemaknaan terhadap fana..$^{40}$

Dalam teori epistemologi, umumnya, dikenal tiga hal yang dapat menjadi sumber atau sarana bagi terciptanya pengetahuan, yaitu akal, indera, dan intuisi. Ketiga hal ini juga diakui sebagai sumber pengetahuan dalam teori epistemologi Islam seperti yang diungkap oleh para filosof dan teolog. ${ }^{41}$ Ketiga hal ini, menurut Naṣr Hāmid Abū Zayd sebetulnya akan lebih tepat jika dikatakan sebagai sarana pengetahuan, sebab dalam tradisi keilmuan Islam, terdapat sebuah sumber yang lebih kuat validitasnya ketimbang ketiga sumber di atas, yaitu teks (nas/wahyu). Sebagian kalangan, bahkan menganggap bahwa teks itulah sebenarnya yang merupakan sumber pengetahuan satu-satunya dalam keilmuan Islam. Sedangkan sumber-sumber lainnya berfungsi sebagai pendukung bagi validitas teks. ${ }^{42}$ Namun demikian, dalam sistem epistemologi Islam, wahyu

${ }^{39}$ Schleifer, Tasawnf di Mesir..., 270.

40Ibid., 271.

${ }^{41}$ Osman Bakar, Hierarki Ilmu: Membangun Rangka Fikir Islamisasi Ilmu, ter. Purwanto (Bandung: Mizan, 1997), 104-9. Mulyadi Kartanegara, Menembus Batas Waktu: Panorama Filsafat Islam (Bandung: Mizan, 2002), 61, dan Menyibak Tirai Kejabilan: Pengantar Epistemologi Islam (Bandung: Mizan, 2003), 18.

${ }^{42}$ Naṣr Ḥāmid Abū Zayd, Mafhüm al-Naṣ: Dirāsah fì 'Ulüm al-Qur'ān (Bayrūt: Markaz al-Thaqāfì al-'Arabī, 1996), 9. 
(agama) telah dianggap sebagai salah satu sumber pengetahuan sebagaimana indera, akal, dan hati. ${ }^{43}$

Dalam konteks epistemologi Islam, pembahasan tentang nazariyyah al-ma'rifah atau yang sering dikenal dengan teori pengetahuan adalah pembahasan yang menitikberatkan pada dasar-dasar dan batasan-batasan dari pengetahuan manusia serta cara-cara untuk sampai kepada pengetahuan. ${ }^{44}$ Ma'rifat dalam bahasa Arab mempunyai banyak penggunaan, tetapi lazimnya ia diartikan sebagai pengetahuan (knowledge), kesadaran (awareness) dan informasi. 45 Namun, adakalanya ia digunakan dalam arti pencapaian khusus (idrāk al-jużìlparticular perception) dan pengingatan ulang (tadhakkur/recognition). Terdapat padanan kata dalam bahasa asing yang merujuk pada suatu teori tentang pengetahuan yang disebut dengan epistemologi (teori pengetahuan). ${ }^{46}$

Teori pengetahuan (nazariyyah al-ma'rifab), meskipun tidak mempunyai sejarah panjang sebagai suatu disiplin ilmu tersendiri, namun bisa dikatakan, bahwa masalah nilai pengetahuan yang menjadi objek pokok masalah ma'rifat telah ada semenjak periode paling awal dalam sejarah filsafat. Faktor yang memicu para pemikir untuk menyelidiki pokok masalah ini adalah tersingkapnya berbagai kekurangan dan kesalahan panca indera dalam mengungkap hakikat-hakikat kejadian eksternal dan sejauhmana akal (intellect) dapat menjawab berbagai pertanyaan yang menyangkut nilai dan kegunaan akal itu sendiri. Persis pada titik inilah kemudian muncul aliran Eleatik yang

${ }^{43}$ Lihat, Bakar, Hierarki Ilmu..., 99-104.

${ }^{44}$ Muḥammad 'Alī Abū Rayyān, al-Falsafah wa Mabāḥithuhā (Mesir: Dār al-Ma'ārif, 1968), 116. Lihat juga, Muhammad al-'Arabī Bū'az̄ìì, Muhammad Iqbāl: Fikerubū al-Dìñ wa al-Falsafì (Bayrūt: Dār al-Fikr al-Mu'āṣir, 1999), 324.

${ }^{45}$ Ayatullāh Muḥammad Tāqī Miṣbāḥ Yazdī, Philoshopical Instruction: An Introduction to Contemporary Philosophy, ter. Muhammad Legenhausen dan 'Azim Sarvdalir (New York: Institute of Global Cultural Studies, 1999), 82.

${ }^{46} \mathrm{Ma}$ 'rifat dalam paradigma tasawuf berarti terbukanya bijāb (penghalang) dan penyaksian Tuhan (mushähadah) sehingga seseorang dapat mengenal Tuhan dengan hati. Ma'rifat juga dalam terminologi tasawuf difahami sebagai proses pengenalan Tuhan yang dilakukan oleh seorang sufi yang tercermin dalam aḥwāl dan maqāmāt. Azyumardi Azra, dkk., Ensiklopedi Tasawuf, jilid 2 (Bandung: Angkasa, 2008), 794-800. 
meragukan segenap pencerapan inderawi (sensory perception). Di sisi lain, perbedaan di antara para pemikir menyangkut masalahmasalah rasional dan adanya pertentangan bukti-bukti untuk mendukung dan meneguhkan suatu gagasan atau pandangan, juga telah memberikan ruang kepada para sofis (shukkäk) untuk sama sekali menolak nilai segenap cerapan rasional. ${ }^{47}$

Al-Kindī, al-Fārābī dan Ibn Sīnā misalnya, menjadikan indera sebagai salah satu sumber utama dari setiap pengetahuan. Pengetahuan indera menurut Al-Kindī sifatnya tidak tetap (gayr thäbitah) secara kualitas dan kuantitas. Pengetahuan tentang halhal yang bersifat parsial sangat tergantung pada indera dan daya imajinasi (al-mutakhayyila) tidak cukup hanya bersandar pada pengetahuan matematis. ${ }^{48}$ Dengan demikian, indera dan akal merupakan sumber utama untuk mencapai pengetahuan. Permasalahannya adalah, apakah indera dan akal juga dapat mengetahui hal-hal yang terkait dengan permasalahan mā warā' al-thabiah (metafisika)?

Dalam konteks inilah, AHM membahas tentang masalah ma'rifat, yakni kemampuannya untuk mendapatkan pengetahuan tentang hal-hal yang terkait dengan persoalan metafisika ( $m \bar{a}$ warä al-tabìah). Dalam pengetahuan secara umum, AHM tidak menafikan indera dan akal sebagai sumber pengetahuan manusia. AHM mengatakan "Kita mengetahui bahwa ada dua cara untuk mendapatkan pengetahuan (ma'rifat) yaitu indera dan akal. Dengan indera, kita akan merasa dan dengan akal kita akan dapat mengambil kesimpulan. Indera dengan berbagai anggotanya dapat mencapai pengetahuan, mata dengan melihat, telinga dengan mendengar, lidah dan tangan dengan perasa. Akal dengan kemampuannya memilah-milah dan mengambil konklusi dapat juga sampai kepada pengetahuan. ${ }^{49}$

Indera adalah salah satu di antara sumber-sumber pengetahuan bagi manusia yang mungkin, karena wilayah kompetensinya hanya menyangkut objek dari dunia eksternal, hingga Ikhwān al-Ṣafā kadang-kadang menamakan panca indera

${ }^{47}$ Yazdī, Philoshopical Instruction..., 86.

${ }^{48} \mathrm{Al}-\mathrm{Kind} \overline{1}$, Rasāill al-Kindī al-Falsafiyyah, ed. Muhạmmad 'Abd al-Hādī Abū Raydah, (Kairo: Matba'ah al-Hassān, 1978), 48-9.

${ }^{49}$ Mahmud, Qadiyyah al-Tașawwuf..., 197. 
itu sebagai indera-indera eksternal atau lahir (al-Hawās al-zăhir ${ }^{50}$ Panca indera adalah sumber pengetahuan yang mula-mula dimiliki oleh manusia, dan yang pertama kali manusia fungsikan untuk mengetahui suatu objek, sejak masih berusia anak-anak. Sebelum mencapai akil balig, manusia dalam batas-batas tertentu sudah memiliki kemampuan mengetahui benda-benda empirikinderawi dengan memfungsikan alat pengetahuan yang dimilikinya berupa indera, sebelum sumber atau alat lain yang dimilikinya yang derajatnya lebih tinggi.

Menurut AHM, panca indera sebagai salah satu sumber pengetahuan, menempati posisi yang paling rendah, selain sebagai alat yang mula-mula yang dimiliki dan difungsikan oleh manusia, panca indera hanya punya kemampuan terbatas menjangkau objek yang berupa realitas-realitas material di dunia fisik (al-mậüsät) yang dalam struktur kosmologi Islam, status ontologisnya berada pada urutan terendah. ${ }^{51} \mathrm{Hal}$ ini, sejalan dengan pendapat para filosof seperti al-Fārābī. Menurut alFārābī, seperti dikatakan oleh Osman Bakar kemampuan mengindera adalah daya mengetahui yang terendah, karena ia hadir demi kemampuan berpikir. ${ }^{52}$

Meskipun panca indera menurut AHM merupakan sumber pengetahuan yang paling rendah peringkatnya bagi manusia, namun, kehadirannya dalam keseluruhan kerangka pengetahuan manusia merupakan suatu kemestian atau bersifat mutlak. Tanpa panca indera, bukan saja tidak mungkin ditangkap objek-objek inderawi di dunia fisik, tetapi juga pengetahuan-pengetahuan tentang objek lain yang berupa realitas, yang status ontologisnya lebih tinggi. Bagaimana mungkin manusia mengetahui objekobjek yang hanya bisa dicapai lewat pengetahuan demonstratif, karena sering, yang tidak bisa diestimasikan oleh daya imajinasi (al-mutakhayyilah) menurut AHM tidak mungkin bisa dikonsepsikan oleh akal fikiran. ${ }^{53}$

${ }^{50} I k h w a ̄ n$ al-Ṣafā, Rasāìl Ikhwān al-Ṣafā, jilid. II (Bayrūt: Dār al-Ṣadar, 1957), 323.

51 Ibid., 334.

52Bakar, Hierarki Ilmu..., 68.

${ }^{53}$ Mahmud, Qadiyyah al-Tasawwuf..., 197. 
Namun, AHM melihat kecenderungan sebagian orang terhadap indera dan akal begitu kuat, hingga membatasi sumber pengetahuan hanya pada indera dan akal, dalam arti mengetahui sesuatu berarti melihat atau merasakannya atau menilainya dari sisi rasionalitasnya tidaklah benar, walaupun sebagian besar manusia, kalau tidak dikatakan mayoritas mengambil pengetahuan yang datang dari dua sumber ini (indera dan akal) sebagai tolok ukur. ${ }^{54}$ Memang, Indera sebagai salah satu sumber pengetahuan dianggap penting, bahkan karena sangat pentingnya, oleh aliran filsafat tertentu seperti aliran empirisme, dipandang sebagai satu-satunya sumber pengetahuan. ${ }^{55}$ Tidak dapat dinafikan, bahwa dengan indera, manusia dapat mengenal dunia di sekelilingnya, mata dapat mengenali bentuk, keberadaan, sifat-sifat dan karakteristik suatu benda. Telinga dapat mendengar suatu dimensi lain dari objek fisik yang tidak dapat dilihat dan dicerap oleh mata. Melalui indera perasa kita mengenal dimensi lain seperti rasa asam, manis, pahit dan lainlain yang tentunya tidak dapat dirasakan oleh mata dan telinga.

Dalam pandangan AHM, banyaknya pengetahuan tentang objek-objek di sekeliling kita yang dapat diketahui oleh indera, bukan kemudian berarti indera dapat mengetahui segala sesuatu seperti yang dikatakan oleh Ibn Hazm dan al-Ījī sebagai sesuatu apa adanya (al-'ilmu bi al-ashä' bimà hua). ${ }^{56}$ Indera dengan berbagai kelebihannya bukan berarti kemudian ia sempurna sebagai suatu sumber pengetahuan. Indera menurut AHM juga mempunyai kekurangan dan keterbatasan. ${ }^{57}$ Berdasarkan pengelihatan kita, kita menduga bahwa bintang yang kita lihat berkelip-kelip di langit ada di sana ketika kita melihatnya, padahal menurut penyelidikan ilmiah bisa saja bintang yang kita lihat sekarang

\section{${ }^{54}$ Ibid.}

${ }^{55}$ M. Amin Abdullah, Aspek Epistimologi Islam dalam Filsafat Islam: Kajian Ontologis, Epistemologis, Akiologis, Historis dan Prospektif, ed. Irma Fatimah (Jogjakarta: Lembaga Studi Filsafat Islam (LESFI), 1992), 28. Mulyadi Kartanagara, Menyibak Tirai Kejahilan Pengantar Episemoogi Islam (Bandung: Mizan, 2003), 18.

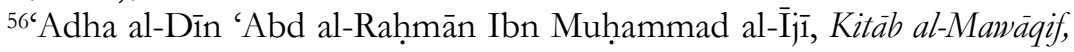
jilid 1 (Bayrūt: Dār al-Jayl, 1997), 52. Lihat juga, Kartanagara, Menyibak Tirai..., 18.

${ }^{57}$ Mahmud, Qadiyyah al-Tașawwuf..., 197-8. 
telah sirna, karena cahaya bintang yang kita lihat sekarang adalah cahaya bintang yang terpancar dari bintang jutaan tahun yang lalu, karena cahaya dari bintang membutuhkan waktu jutaan tahun untuk sampai ke mata kita. ${ }^{58}$ Suara dentuman gunung berapi yang kita dengar tidak terjadi pada saat kita mendengarnya, karena gelombang suara membutuhkan waktu beberapa saat untuk sampai ke telinga kita. Telinga juga tidak mampu mendengar semua gelombang suara, karena telinga hanya mampu mendengar suara yang berfrekuansi tertentu saja, dan bukan gelombang suara yang jauh di luar batas frekuansi pendengaran, apalagi jika terjadi gangguan pada telinga, maka bisa saja pendengaran akan terganggu. Mata melihat pasir di gurun pasir yang panas seolah-olah kolam air. Melihat kelemahan indera, manusia menjadi sadar bahwa ia tidak bisa sepenuhnya bersandar pada pengalaman atau pengetahuan yang dihasilkan oleh indera, bahkan semakin hari kelemahan itu pun semakin tersingkap. ${ }^{59}$ Belum lagi, jika pengetahuan tersebut terkait dengan permasalahan-permasalahan yang bersifat non fisik dan kejiwaan (psikologis).

Demikian AHM melihat bahwa indera terbatas dalam mengakses pengetahuan dan banyak melakukan kesalahan. Kalau demikian, sumber apalagi yang digunakan oleh manusia untuk menghasilkan pengetahuan? AHM mencoba mencari jawaban ini pada mazhab rasionalis yang bersandar pada kemampuan akal manusia. Namun lagi-lagi, ia melihat tidak adanya kesepakatan antara kaum rasionalis dalam satu masalah dan bahkan cenderung terjadi pertentangan antara satu kelompok dengan kelompok yang lain, terutama yang terkait dengan permasalahan-permasalahan metafisika. Lagi pula, setiap orang mempunyai kemampuan rasional yang berbeda-beda, yang sering kali banyak dipengaruhi oleh berbagai faktor eksternal seperti lingkungan, sosial dan politik. ${ }^{60}$

\footnotetext{
${ }^{58}$ Kartanagara, Menyibak Tirai..., 19.

${ }^{59}$ Mahmud, Qadiyyah al-Tașawnuf..., 197.

${ }^{60}$ Abdul Halim Mahmud, Al-Islām wa al-'Aql (Kairo: Dār al-Ma'ārif, t.t.), 8. Lihat juga Abdul Halim Mahmud, Al-Tafkeir al-Falsafi fi al-Isläm (Kairo: Dār al-Ma'ārif, t.t.), 175.
} 
AHM mengakui bahwa di samping kerap terjadi kesalahan dalam proses penalaran rasional, juga pengetahuan yang diperoleh akal melalui panca indera kadang-kadang mengalami distorsi pada tahap tangkapan indera, yakni bila ada faktor-faktor luar yang mengganggu objektivitas atau tingkat akurasi indera, atau, pada tahap bentukan hayal (khayāl) dan wahm, di mana keduanya sering mengaburkan akal dalam menangkap objek metafisika dengan mengesankan kesan-kesan fisis-sensual seperti warna, bentuk, dan bereksistensi dalam ruang dan waktu. Maka untuk mencapai kebenaran ilmu-ilmu inferensial, diperlukan penalaran yang sahih. Khusus dalam masalah metafisika, ia harus jernih dari khayaal dan wahm, serta dibutuhkan adanya petunjuk langsung dari Allah Swt. yang menyingkap esensi segala sesuatu sejelas-jelasnya. ${ }^{61}$

Karena itu, AHM berpendapat bahwa hal-hal yang terkait dengan permasalahan-permasalahan metafisika ( $m \bar{a}$ warà altabi'ab) adalah hal-hal yang bersifat gaib, karena itu, ia bukanlah lapangan yang dapat dicapai oleh indera dan akal. ${ }^{62}$ Dalam hal ini, akal hanya sampai kepada praduga karena sifatnya yang spekulatif. Akal seperti yang dikatakan oleh Mulyadi, tidak mengerti banyak tentang pengalaman-pengalaman eksistensial, yaitu pengalaman-pengalaman yang langsung dirasakan, dan bukan yang dikonsepsikan, disamping itu akal juga sering meruang-ruang (spatilize), hingga cenderung memahami sesuatu secara general dan homogen. ${ }^{63}$ Akal juga tidak mampu mengetahui objek penelitiannya secara langsung, karena akal dengan menggunakan kata-kata atau simbol hanya akan berputar-putar di sekitar objek tersebut, tetapi tidak pernah secara langsung dapat menyentuhnya. ${ }^{64}$

Al-Gazālī dalam hal ini, memberikan peran kepada akal lebih tinggi dari yang diberikan oleh AHM. Menurutnya, akal merupakan inti hakikat kemanusiaan yang membedakan sosok manusia dari hewan dan setan. Akal, sebagai 'cermin' yang dapat menangkap objek sebagaimana adanya, adalah bersih dari

\footnotetext{
${ }^{61}$ Mahmud, Al-Isläm wa al'Aql..., 61.

62Mahmud, Qadiyyat al-Tasammuf..., 249

${ }^{63}$ Kartanegara, Menyibake Tirai..., 27.

${ }^{64}$ Ibid., 27.
} 
kesalahan. Seandainyapun pemikiran seseorang dinyatakan salah, maka kesalahannya bukanlah terletak pada akal, tetapi karena ia dikuasai oleh khayal (khayalan) dan wahm (keragu-raguan). Akal bila bersih dari gangguan khayal dan wahm, tak terbayang akan keliru, dan dapat menangkap sesuatu sebagaimana realitasnya. ${ }^{65}$

Al-Gazali menganggap penolakan seseorang terhadap akal lebih disebabkan dikarenakan tiga hal. Pertama, kerusakan akal sang penolak seperti kaum sofis (syukekäk). Kedua, kesalahan orang-orang yang mengidentikkan akal dan ilmu-ilmu rasional dengan polemik apologik dan produk-produk ilmu kalam, sehingga sebagian sufi menolak akal. ${ }^{66}$ Ketiga, terjadinya kesalahan dalam proses penalaran rasional seseorang, baik pada bentuk silogisme, maupun pada premis-premisnya, atau skeptik terhadap konklusi dan premis-premisnya. ${ }^{67}$

Menurut AHM, satu-satunya yang dapat memberikan pengetahuan tentang hal-hal yang gaib adalah intusi (bașirah). Intuisi menurutnya, dapat berupa ilham, mimpi dan penyingkapan (kashf). Di dalam al-Qur'an, ada berbagai macam ayat yang menunjukkan kemungkinan pengetahuan ini. Misalnya dalam surat Yūsuf, diceritakan berbagai mimpi yang dapat dipahami oleh Yūsuf yang merupakan isyarat terhadap kejadian masa depan, kisah Nabi Khidir dengan Nabi Mūsā dan lain-lain. Bahkan dalam hadis dikatakan, bahwa mimpi adalah seperempat puluh enam bagian kenabian. ${ }^{68}$ Pengetahuan intuitif inilah yang kemudian oleh para sufi disebut dengan kashf (penyingkapan) dan mushähadah (penyaksian). ${ }^{69}$

AHM melihat bahwa akal dengan keterbatasannya tidak mampu mengungkap dan menangkap pengalaman-pengalaman spiritual. Akal juga dengan berbagai tingkatannya mempunyai persepsi yang berbeda-beda terhadap suatu permasalahan

${ }^{65}$ Imām Al-Gazālī, Mìyār al-'Tlm, ed. Sulaymān Dunyā (Kairo: Dār alMa'ārif, 1960), 59.

${ }^{66}$ Imām Al-Gazālī, Ihyà' 'Ulūm al-Dìn, jilid I (Beirūt: Dār al-Kutub al'Ilmiyyah, t.t.), 33.

67al-Gazālì, Mi'yār al-'Tlm..., 219.

${ }^{68}$ Mahmud, Qadiyyah al-Tasawwuf..., 250.

${ }^{69}$ Ibrāhīm Hilālī, al-Tasawwuf al-Islämi bayn al-Dìn wa al-Falsafah (Kairo: Dār al-Naḍah al-'Arabiyyah, 1979), 49. 
disebabkan pengaruh lingkungan dan intelektualitas seseorang. Sedangkan pengetahuan intuitif (basirah), adalah pengetahuan "eksperiensial" yang didasarkan pada pengalaman yang dapat memahami suatu peristiwa dengan lebih mendalam. Dalam terminologi tasawuf, hal ini menjadi mungkin, ketika seorang sufi ber-mujăhadah dan selalu mendekatkan diri pada Tuhan, sehingga Tuhan dengan kecintaan-Nya membukakan baginya perbendaharaan pengetahuan yang disebut dengan ma'rifatulläh atau pengetahuan tentang Tuhan, atau dalam bahasa al-Gazālī disebut juga dengan ilmu laduni. ${ }^{70}$

Demikianlah secara garis besar, AHM melihat ada tiga aliran pokok dalam teori epistemologi Islam. Pertama, aliran rasionalis yang dimotori oleh para filosof peripatetik dan sebagian kelompok mutakallimin. Aliran ini menekankan pentingnya peran akal sebagai sumber dan alat pengetahuan. Kedua, kelompok empirisme yang menyatakan pentingnya peran inderawi dalam memperoleh pengetahuan. Ketiga, kelompok yang menyatakan bahwa hati adalah sumber bagi pengetahuan yang hakiki yang dimotori oleh para sufi.

Dalam praktiknya, seperti yang dikatakan oleh Amin Abdullah, ketiga aliran ini saling bersiteguh mempertahankan keyakinan masing-masing yang kadang-kadang terlihat sangat eksklusif. ${ }^{71}$ Dalam hal ini, penulis melihat kecondongan AHM terhadap pengetahuan yang diperoleh melalui hati seolah-olah menafikan kontribusi akal dalam mendapatkan pengetahuan metafisis, padahal prilaku rohani seperti yang diungkapkan oleh Taqī Misbah Yazdī, seorang filosof Iran, sama sekali tidak berseberangan dengan filsafat ketuhanan yang didasarkan pada pencapaian rasional, malahan yang pertama (tasawuf) banyak dibantu dan mengambil manfaat dari filsafat (akal). Menurut Yazdī, harus diakui bahwa secara keseluruhan pertentangan semacam ini hanya berguna untuk mencegah kejumudan dan ekstrimisme, serta memperjelas garis batas yang memisahkan antara kedua bidang tersebut karena akal telah menjadi pelayan yang berguna dan tak tergantikan bagi Islam dengan cara menjelaskan ajaran-ajarannya yang agung pada satu sisi, dan

${ }^{70}$ Mahmud, Qadiyyah al-Tasawnuf..., 196.

${ }^{71}$ Abdullah, Aspek Epistimologi..., 30. 
dengan cara mempertahankannya dari sergapan aliran-aliran atau mazhab-mazhab yang memusuhinya pada sisi lain. Begitulah yang telah dan terus akan dilakukan akal terhadap ajaran-ajaran Islam. ${ }^{72}$

\section{Korelasi Akal dan Naql}

Pembahasan tentang korelasi antara akal dan naql pada dasarnya merupakan implikasi dari berbagai pembahasan teologis ataupun filosofis yang menyangkut masalah sumber pengetahuan dan sejauhmana otoritas dan validitasi sumbersumber tersebut. Bahasan ini (korelasi antara akal dan naq) tidak hanya berlaku dalam sistem teologi Islam, namun juga menjadi bahasan berbagai agama dan keyakinan. Sa'ad al-Fayyūmī seperti dikatakan oleh Muḥammad Yūsuf Mūsā memandang bahwa doktrin-doktrin agama (akidah) membutuhkan akal untuk menjelaskan ajaran-ajaran dan membentenginya dari berbagai doktrin-doktrin yang menyimpang. ${ }^{73}$

Dalam sejarah pemikiran Islam, persoalan relasi atau hubungan antara akal dan wahyu merupakan isu yang selalu hangat diperdebatkan oleh para mutakallimin dan filosof. Pembahasan ini menjadi penting, karena ia memiliki kaitan dengan argumentasi-argumentasi mereka dalam pembahasan tentang konsep Tuhan, etika dan lain-lain. Orientasi mereka seperti yang dikatakan A.J. Arberry adalah untuk membuktikan kesesuaian atau hubungan antara akal dan wahyu. ${ }^{74}$

Dalam teologi Islam misalnya, ada konsep tentang "kebaikan dan keburukan". Konsep tentang kebaikan dan keburukan ini menurut para filosof dan golongan Mu'tazilah dapat diketahui oleh akal (al-husnu wa al-quḅ̣u 'aqlìyayn). Artinya, akal dapat menetapkan dan menilai berbagai perbuatan dan tindakan, serta menghukumi baik dan buruknya atau benar dan salahnya suatu perbuatan. ${ }^{75}$ Akal dapat menetapkan perbuatan bahwa keadilan

${ }^{72}$ Yazdī, Philoshopical Instruction..., 123.

${ }^{73}$ Muhạammad Yūsuf Mūsā, Bayn al-Dìn wa al-Falsafah fì Ra'yi Ibn Rushd wa Falāsifah al-'Așr al-W asịt (Mesir: Dār al-Ma'ārif, tt.), 102.

${ }^{74}$ Arberry, Revelation and..., 10.

${ }^{75} \mathrm{Al}-\mathrm{Shahrastān} \overline{1}$, Al-Milal wa al-Niḥal, ed. Aḥmad Faḥmī Muḥammad, (Bayrūt: Dār al-Kutub al-'Ilmiyyah, 1990), 39. 
itu adalah baik, kejujuran adalah baik, dan kebohongan adalah buruk. Dalam konteks ini, akal dengan tanpa bantuan wahyu dapat menunjukkan pada manusia, mana keadilan dan kejujuran yang harus dimiliki dan dilakukan, serta mana kebohongan dan ketidakadilan yang harus dijauhi dan ditinggalkan. Karena itu, jika pengetahuan akal tentang yang baik dan buruk dinafikan, maka syariat seperti kata al-Ṭūsī tidak dapat ditegakkan. Naṣir alDīn al-Ṭūsī mengungkapkan, "Harus ditegaskan bahwa baik dan buruk dapat diketahui akal (al-ḅusnu wa al-qubḅu 'aqlìyayi), karena keduanya berkaitan erat dalam keberadaan dan keabsahan syariat". ${ }^{76}$ Artinya, jika akal tidak dapat menetapkan kebaikan dan keburukan, maka syariat tidak dapat ditetapkan, karena bohong misalnya, jika menurut akal tidak buruk, maka manusia tidak akan dapat menilai perkataan jujur para Nabi adalah baik. Manusia juga tidak akan dapat mengetahui bahwa para Nabi pasti tidak berbohong. ${ }^{77}$

Namun hendaklah terlebih dahulu dipahami bahwa perbedaan pandangan tentang hubungan antara akal dan wahyu tidaklah menyangkut fungsi akal, tetapi semata-mata tentang ruang lingkup dan hal-hal mana yang boleh dimasuki oleh akal, yakni sejauhmana akal dibenarkan untuk bekerja. Sebab, baik alQur'an maupun hadis Nabi sangat menekankan pentingnya kegiatan berpikir. Dalam al-Qur'an, terdapat begitu banyak ayat mendorong kaum muslimin untuk menggunakan akalnya. Sementara itu, Nabi Muhammad menyatakan persetujuannya terhadap sikap Mu'ādh bin Jabal yang akan menggunakan akalnya untuk berijtihad bila tidak menemukan nash yang sahih dalam al-Qur'an maupun hadis. ${ }^{78}$

Menurut AHM, asal usul filsafat Islam harus ditemukan dalam al-Qur'an, karena al-Qur'an mendorong penelitian rasional. ${ }^{79}$ Ia menegaskan bahwa al-Qur'an terdiri dari akidah

${ }^{76}$ Nașīr al-Dīn al-Ṭūsī, Kashf al-Murād fì Sharḥ al-Tajrìd al-I'tiqād, (Kairo: Dār al-Ma'ārif, t.th), 423.

${ }^{77}$ Al-Shahrastānī, al-Milal wa al-Niḩal..., 39.

${ }^{78} \mathrm{Imām}$ al-Tirmidzī, Sunan al-Tirmidhī, Kitāb al-Aḥkam, no. 1249 (CD ROOM).

${ }^{79}$ Di antara ayat-ayat yang disebutkan oleh Abdul Halim Mahmud, terdapat dalam surat al-Baqarat ayat (2): 170, al-A'rāf (7): 179-185. Ayat ayat 
dan syariat. Syariat adalah sejumlah peraturan yang diilhami oleh akidah dan dirancang untuk memenuhi tuntutan-tuntutan kehidupan manusia yang selalu berubah-ubah. Dalam pengertian ini, filsafat adalah pembahasan rasional tentang prinsip-prinsip hukum yang mempunyai tujuan praktis. Menurut AHM, alQur'an bukan sekedar kitab etika dan moral. Tetapi al-Qur'an adalah dasar bagi seluruh kegiatan hukum, teologi, mistik dan filsafat. Keunggulannya adalah menggabungkan keyakinan dan akal. Al-Qur'an menurutnya adalah penjelasan yang nyata (bayān) bagi manusia yang menjelaskan tentang ketuhanan, alam, manusia, dan etika.

Namun demikian, ini bukan berarti bahwa harus menyandarkan segala permasalahan kepada kekuatan rasional (akal). Menurut AHM, ada hal-hal di mana akal tidak bisa menjadi ukuran dari suatu kebenaran, karena mempunyai keterbatasan-keterbatasan terutama dengan hal-hal yang di luar kemampuan akal. Karena itu, al-Qur'an menurut AHM diturunkan sebagai petunjuk bagi akal dalam permasalahan tertentu yang tidak dapat dijangkau oleh akal. Dalam hal ini seorang mukmin harus berserah diri kepada agama atau dalam bahasa AHM istislam al-wajh. Permasalahan-permasalahan tersebut menurutnya adalah; pertama, permasalahan metafisika (mā warà' al-tabi'ab) seperti keyakinan tentang Allah dan rasulNya, dan hari kiamat. Kedua, akhlak yang terkait dengan permasalahan baik dan buruk. Ketiga. Permasalahan syariat yang telah diatur dalam al-Qur'an yang menyangkut kebahagiaan dan hajat orang banyak. ${ }^{80}$

Karena itu, seperti juga dikemukakan oleh al-Gazālī, bahwa akal dan naql adalah dua unsur yang mempunyai relasi komplementer. Secara alegoris al-Gazālī menggambarkan keduanya seperti mata dan cahaya dalam makna bahwa akal tidak akan mendapatkan hidayah (petunjuk) kecuali dengan shara', sebagaimana shara' tidak mudah dipahami tanpa akal. ${ }^{81}$ Secara

ini menurut Abdul Halim Mahmud adalah ajakan untuk memakai akal dalam melihat kebesaran Tuhan. Mahmud, Al-Isläm wa al'Aql..., 15.

${ }^{80}$ Ibid., hal. 17-18.

${ }^{81}$ Imām al-Gazālī, Ma'àrij al-Quds fì Madārij Ma'rifah al-Nafs, ed. Shekh Muḥammad Muṣțafā Abū al-’Ulā (Kairo: Maktabah al-Jundi, 1968), 73. 
simbiosis, keduanya saling memerlukan, eratnya relasi akal dan naql yang kohesif dan saling membutuhkan ini, digambarkan dengan contoh-contoh yang menempatkan tidak berguna dan bermaknanya salah satu dengan sebab hilangnya yang lain.

Perdebatan tentang fungsi dan peran akal di kalangan umat Islam, muncul ke permukaan ketika harus berhadapan dengan filsafat Yunani yang membicarakan persoalan-persoalan teologis dengan bukti dan argumentasi-argumentasi rasional. Mu'tazilah mempunyai andil dalam kematangan kajian-kajian rasional. Berdasarkan kenyataan ini, Aḥmad Amīn menyatakan bahwa "ilmu kalam mencapai kematangan pada masa Abbasiyyah, dan yang memberikan andil paling besar dalam proses kematangannya adalah Mu'tazilah. ${ }^{82}$

Islam menurut AHM telah mengembangkan sebuah sistem teologi dengan dua tujuan. Pertama, merefleksikan secara filosofis persoalan-persoalan dan masalah-masalah yang muncul dalam kekhalifahan Islam yang baru terbentuk. Kedua, membela doktrin-doktrin Islam, khususnya doktrin tauhid dari filsafatfilsafat dan teologi-teologi non Islam yang saling menyerang. Inilah kemudian secara formal membentuk bangunan ilmu kalam pada fase awal Islam. ${ }^{83}$ Interpretasi rasional Mu'tazilah terhadap masalah-masalah akidah didasarkan atas anggapan bahwa akal mempunyai kedudukan yang tinggi dalam memahami agama, terutama yang berkaitan dengan Tuhan. Karena itu, Mu'tazilah menurut Imam al-'Ash'ari berdiri menggunakan filsafat, bahkan, untuk tujuan-tujuan agama sekalipun. ${ }^{84}$

Sejalan dengan perkembangan Islam, dan adanya berbagai konflik intern umat Islam memunculkan kelompok-kelompok keagamaan (al-ab̧āab al-diniyyah) dan golongan-golongan keagamaan (al-firaq al-diniyyah) dimana masing-masing

${ }^{82}$ Aḥmad Amīn, Zuhr al-Islām (Bayrūt: Dār al-Kitāb al-'Arabī, 1969), 1.

${ }^{83 ‘ A l i ̄ ~ S a ̄ m i ̄ ~ a l-N a s h a ̄ r ~ d a l a m ~ k a r y a n y a ~ N a s h ’ a h ~ a l-F i k e r ~ a l-F a l s a f i ̀ ~ f i ̀ ~ a l-I s l a ̄ m ~}$ membagi sebab-sebab kemunculan pemikiran filsafat dalam Islam kedalam dua katagori, internal dan eksternal. Faktor internal seperti politik, bahasa dan ekonomi. Sementara faktor eksternal, seperti agama Yahudi, Nasrani, filsafat Yunani dan aliran Gnosis. Lihat lebih lanjut, al-Nashār, Nash'ah alFiker..., jilid 2, 62-3.

${ }^{84}$ Imām Abū Hasan al-'Ash'arī, Maqālāt Islämiyyìn wa Ikhtiläf al-Musallìn, vol. 2 (Kairo: Maktabah al-Nahụah al-Miṣriyyah, 1950), 25. 
menganggap kelompoknyalah yang paling benar. Dalam hal ini, sebagian kelompok mengambil amunisinya dari filsafat Yunani yang berkembang saat itu di dunia Islam, sehingga ilmu kalam tidak ubahnya seperti filsafat. Bahkan ia menyatakan, bahwa umat Islam sudah semakin jauh dari al-Qur'an dan semakin dekat dengan filsafat, sehingga bahasannya adalah bahasan filsafat semata, atau paling tidak mendekati kepada kelompok Mu'tazilah. ${ }^{85}$

Hal pertama yang disoroti oleh AHM adalah permasalahanpermasalahan yang terkait dengan metafisika. Menurutnya, ilmu kalam dan filsafat telah keluar dari kaidah-kaidah yang telah ditetapkan oleh Rasulullah dan para salaf al-șalih. Karena itu, perlu dilakukan apa yang ia sebut sebagai al-hadm wal binä' atau dekonstruksi terhadap pembahasan-pembahasan dalam ilmu kalam dan filsafat. AHM ingin menghilangkan tema-tema yang ia anggap dalam kategori ayat-ayat mutashäbihät yang terkait dengan permasalahan metafisika dengan melakukan pendekatan rasional. ${ }^{86}$ Namun sayangnya, AHM justru kemudian terjebak kepada pendapat-pendapat dari kelompok Salafiyah, yang tidak setuju dengan pembahasan metafisika karena dianggap dapat menyebabkan bid'ah dan penyelewengan terhadap metafisika Ilahiyah. Namun demikian, penolakan kaum Salaf ini menurut al-Nashār adalah hal yang aneh, karena dengan penolakan itu pada dasarnya mereka telah membentuk ilmu kalam yang baru. ${ }^{87}$

Di lain pihak, mengikuti jejak Imām al-Gazālī, AHM berpendapat bahwa ilmu kalam memberikan pembelaan rasional bagi ajaran-ajaran Islam, namun tidak pada hal berkaitan dengan metafisika karena khawatir akan adanya perdebatan yang mengakibatkan perpecahan di kalangan umat Islam. ${ }^{88}$

Sikap Mu'tazilah yang memberi porsi sangat besar kepada akal dalam memahami agama terlihat dari pandangannya yang menyatakan bahwa akal dapat mengetahui yang baik dan buruk. Akan tetapi, interpretasi rasional Mu'tazilah tidak sepenuhnya dapat diterima oleh kaum muslimin. Abl al-hadith misalnya,

\footnotetext{
${ }^{85}$ Mahmud, Al-Isläm wa al-'Aql..., 40.

86Ibid., 115.

${ }^{87}$ al-Nashār, Nash'ah al-Fiker al-Falsafï..., 61.

${ }^{88}$ Mahmud, Al-Isläm wa al-'Aql..., 9; Mahmud, Al-Tafkì al-Falsafi..., 175.
} 
menolak interpretasi rasional karena dua sebab. Pertama, kemampuan akal terbatas, sedangkan wahyu adalah kebenaran al-Qur'an bersifat mutlak. Sesuatu yang terbatas menurut mereka, tidak bisa menjelaskan yang mutlak. Kedua, interpretasi seperti itu dianggap akan mengganggu keyakinan orang awam. ${ }^{89}$

AHM sepakat dengan para ulama yang berpendapat bahwa akal, sebagaimana halnya wahyu, adalah anugerah Tuhan yang dengannya seseorang menjadi manusia yang membedakannya dari makhluk-makhluk lain. Akan tetapi AHM menganggap wahyu lebih tinggi kedudukannya dari akal, kebenaran wahyu bersifat mutlak, sedangkan kebenaran akal bersifat relatif dan nisbi. Karena kebenaran akal relatif, maka AHM menolak adanya "akal manusia" dalam makna akal universal, yang ada menurutnya hanyalah akal individu-individu serta akal komunitas-komunitas dalam lingkungan tertentu yang dipengaruhi oleh berbagai faktor. ${ }^{90}$ Karena tidak ada yang dinamakan akal universal, maka kebenaran akal bersifat nisbi, sekalipun ia diterima oleh banyak orang. Sebab, individu atau kelompok yang lain yang berada di lingkungan yang berbedabeda dan terpengaruh oleh berbagai faktor yang berbeda pula. Dengan demikian, tidak mungkin ada kebenaran rasional yang objektif, dalam pengertian dapat diterima oleh semua orang. ${ }^{91}$

Karena itu, menurut AHM, agar bisa mendapatkan kebenaran yang objektif, yang dapat diterima semua orang, maka harus ada tolok ukur yang dapat mempertemukan akal yang banyak dan berbeda-berbeda tersebut, harus berada di luar manusia, dan itu adalah agama (wahyu). ${ }^{92}$ Dengan demikian, AHM menempatkan akal tidak sejajar dengan wahyu, namun berada di bawahnya. Konsekuensinya, setiap kesimpulan baru dipandang benar, manakala ia tidak bertentangan dengan wahyu, sebaliknya, jika terdapat nash atau teks wahyu yang tidak dapat dipahami oleh akal, atau "bertentangan" dengan akal, AHM memilih cara tawaquf dari pada ta'mil atau interpretasi rasional.

${ }^{89}$ Aḥmad Fu'ād al-Ahwānī, Ibn Rushd dalam A History of Muslim Philosophy ed. M.M. Syarif.

${ }^{90}$ Mahmud, Al-Islàm wa al-'Aql..., 108.

${ }^{91}$ Mahmud, Al-Tafkìr al-Falsafï..., 175.

${ }^{92}$ Mahmud, Al-Islàm wa al-'Aql..., 11. 
Setiap ketetapan hukum yang menyangkut perintah dan larangan, baik dan buruk, ditetapkan oleh Tuhan berdasarkan firman-Nya yang di dalamnya terdapat alasan, tujuan dan hikmah tertentu yang dimaksudkan dan ditujukan untuk kemaslahatan manusia (masäliḥ al-ibād). Yang tahu pasti tentang tujuan dan hikmah tersebut hanyalah Allah. Dengan demikian menurut AHM, kedaulatan hukum sepenuhnya berada di tangan Allah, dan tidak ada hak sedikitpun bagi manusia untuk campur tangan di dalamnya. Karena itu, yang halal tetap halal dan yang haram akan tetap haram. Perkembangan ilmu pengetahuan manusia kadang-kadang dapat menyingkap salah satu hikmah pelarangan, akan tetapi hikmah tersebut bukanlah satu-satunya, sebab di balik hikmah tersebut terdapat hikmah lain yang tidak diketahui manusia. Bahkan menurut Sayyid Quțub, dengan perkembangan ilmu pengetahuan juga terjadi perubahan dalam hikmah karena munculnya teori yang lain. Karenanya, kepastian dan ketentuan hanya dapat diberikan oleh pedoman hidup yang tetap, dan tidak berubah-ubah. ${ }^{93}$

Akal manusia menurut AHM hanya dapat mengetahui dan mengungkap hal-hal lahiriah dari suatu ketentuan Tuhan, dan akal tidak akan mampu mengungkap rahasia-rahasia terdalam. Dalam kitabnya al-Isläm wa al-'Aql, AHM mengilustrasikan pendapatnya dengan mengungkap suatu cerita. Cerita itu mengungkapkan seorang ayah yang membuat rumah untuk anaknya di atas pegunungan dengan dikelilingi oleh pohon hashis yang harum baunya. Sang ayah berwasiat agar pohon-pohon tersebut jangan sekali-kali ditebang. Namun, ketika sang ayah telah meninggal, sang anak menebang pohon-pohon tersebut dan menggantikannya dengan pohon-pohon yang lebih bagus dan lebih harum. Karena yang dipahami oleh sang anak dari wasiat ayahnya untuk tidak menebang pohon karena bau bunga tersebut harum, maka ketika sang anak mendapatkan bunga yang lebih harum, ia merasa tidak ada alasan lagi untuk mempertahankannya. Namun, ketika pohon-pohon tersebut ditebang, maka pada malam harinya bermunculanlah ular-ular di

\footnotetext{
${ }^{93}$ Sayyid Quṭub, Fì Zilāl al-Qur'ān, jilid 5 (Bayrūt: Dār al-Shurūq, 1980), 670.
} 
sela-sela pepohonan. ${ }^{94}$ Dengan demikian menurut AHM, yang dilakukan manusia bukanlah menilai ketentuan agama dengan persepsi-persepsi yang dimilikinya berdasarkan kategori-kategori logika, atau melalui pengalaman-pengalaman empirik yang terbatas, tetapi dengan menerima nash-nash yang benar, kemudian dari situ, ia membentuk persepsi-persepsinya.

Atas dasar ini, AHM sebenarnya tidak menolak akal, bahkan ia mengakui kemajuan peradaban manusia berhutang kepada akal. namun yang dilakukannya adalah membatasi ruang geraknya. Menurutnya akal tidak berhak menentukan yang baik dan yang buruk karena ia tidak tahu secara pasti hikmah dan tujuan dari ketentuan-ketentuan Tuhan. Ketentuan-ketentuan tersebut hanya dapat diketahui melalui wahyu, tugas akal adalah memahami wahyu tersebut dan mencari dalil-dalil rinci bagi terapannya yang dapat menguatkan ketentuan wahyu tersebut dengan bimbingan kaidah-kaidah umum yang diberikan alQur'an dan sunnah. ${ }^{95}$

Menurut AHM, agama bukanlah persoalan persepsi atau kebebasan berpendapat, tetapi beragama adalah berarti penyerahan diri kepada otoritas Tuhan yang tercermin dalam keyakinan terhadap teks-teks agama. Dalam hal inilah, ia menyatakan bahwa al-Qur'an adalah petunjuk bagi akal, karena itu, akal harus tunduk dan bersujud kepada wahyu Ilahi. AHM menafsirkan firman Allah surat al-Hashr ayat 2 dengan mengatakan bahwa makna "fa'tabirü" adalah mengambil pelajaran dalam arti berpikirlah, agar engkau mengetahui bahwa itu adalah benar, atau berpikirlah, agar engkau mengetahui bahwa itu adalah baik, dan jika ada hal yang tidak sesuai dengan akalmu, sesungguhnya kesalahan itu bukan pada wahyu namun pada akalmu. Bahkan lebih jauh dengan mengutip ungkapan Abū Sulaymān al-Mantiqī, "Jīka saja akal sudah cukup bagi manusia, lalu apa fungsi dan manfaat wahyu? ${ }^{96}$ Dalam hal ini, terlihat bahwa AHM ingin menyatakan bahwa, jika ada perbedaan antara akal dan wahyu, maka akallah yang harus dipersalahkan.

\footnotetext{
${ }^{94}$ Mahmud, Al-Isläm wa al'Aql..., 27-8.

${ }^{95}$ Mahmud, Al-Tafkìr al-Falsafï..., 104.

${ }^{96}$ Mahmud, Al-Islàm wa al'Aql..., 22.
} 
Karena itu, AHM memetakan pola hubungan antara akal dan naql dalam lima kategori. Pertama, naql diturunkan sebagai petunjuk (hädiya) bagi akal dalam permasalahan-permasalahan metafisika seperti permasalahan ketuhanan dan hari kiamat, permasalahan etika yang terkait dengan baik dan buruk dan apa yang seharusnya dilakukan untuk menjadi orang yang baik dan permasalahan syariat yang menyangkut kepentingan orang banyak. Kedua, naql diturunkan untuk memberi pemahamn kepada akal dalam permasalahan muḅkam dan mutashäbih. Ketiga, naql datang untuk meyakinkan akal. Keempat, naql datang tidak untuk bernegosiasi dengan akal. Kelima, naql datang untuk mengajak manusia menuju kesempurnaan jiwa (spritual). ${ }^{97}$

Ibn Rushd seorang filosof Andalusia yang hidup sebelum AHM, dengan ayat yang sama menekankan peran akal. Menurutnya makna i'tibār dalam kalimat 'fa'tabir $\vec{u}$ ' adalah mengambil hukum sesuatu yang tidak diketahui (majhüh) dari yang diketahui (ma'lüm) yang pada dasarnya merupakan analogi filosofis. Akal menurutnya tidak bertentangan dengan wahyu karena keduanya mencari dan mencerminkan kebenaran yang sama walaupun dengan cara yang berbeda. Kalaupun terlihat terjadi pertentangan dengan lahir teks, maka wahyu harus dita'wilkan sehingga terjadi keselarasan. ${ }^{98}$

Pola dan relasi antara akal dan naql yang dikembangkan oleh AHM tidak sedetail yang dikembangkan oleh al-Gazālī, walaupun keduanya sepakat akan keterbatasan akal dan otoritas wahyu (naq) dalam membimbing akal. al-Gazālī misanya, memetakan pola hubungan antara akal dan naql dengan empat macam yaitu taqrir, tanbih, tadhkir dan ta'lim. ${ }^{99}$ Taqrir atau pengakuan yaitu hubungan yang terjadi apabila permasalahanpermasalahan universal yang diketahui akal sesuai dengan yang diketahui shara' (agama). Dalam hal ini, shara' memberikan pengakuan terhadap pengetahuan akal. Tanbih atau penyadaran, yaitu hubungan yang terjadi apabila akal lalai. Dalam kondisi seperti ini, shara' datang memperjelas dalil (ižhär al-dalīl) sehingga

${ }^{97}$ Ibid., 17-21.

${ }^{98} \mathrm{Ibn}$ Rushd, Fașl al-Maqāl fì mà Bayn al-Hikmah wa al-Syarìah min alIttisāl, (Kairo: Dār al-Ma’ārif, t.t.), 30-4.

${ }^{99} \mathrm{Al}-\mathrm{Gazāl} \overline{1}, M a$ àrij al-Quds..., 74. 
akal menjadi sadar. Atau dengan ungkapan lain, akal terpengaruh oleh banyak faktor sehingga tidak menuju kepada pengetahuan yang benar, sehingga akal membutuhkan petunjuk yang dapat menyadarkannya. Tadhkir atau pengingat yaitu hubungan yang terjadi manakala akal kehilangan pengetahuan karena faktorfaktor tertentu sehingga datanglah shara' untuk mengingatkannya. Ta'tim atau pengajaran yaitu hubungan yang terjadi apabila akal sama sekali belum memiliki pengetahuan. ${ }^{100}$

Dalam konteks epistemologi Islam, apa yang diungkapkan oleh AHM tentang relasi antara akal dan naql adalah cerminan epistemologi bayānì yang berusaha memposisikan ketundukan akal terhadap naql. Pola hubungan yang terjalin di sini bukanlah hubungan yang setara, melainkan pola hubungan yang bertingkat. Pola hubungan bertingkat ini mengandaikan sebuah sumber menduduki tingkatan yang lebih tinggi dari pada yang lainnya. Dalam hal ini teks (naq) lebih tinggi dari sumbersumber yang lain dan harus tunduk secara mutlak kepada naql, dengan kata lain, teks (naq) menjadi aṣl (pokok), sedangkan akal, menjadi far' (cabang), dan far' harus selalu tunduk pada as $l_{.101}$

Namun, konsepsi AHM yang berlatarbelakang pencarian kebenaran, pada gilirannya berakhir dengan sikap yang kurang apresiatif terhadap akal. AHM lebih menghargai intuisi ketimbang akal. sebab menurutnya, kemampuan akal ini adalah terbatas dan kerap menipu. Pandangan ini pulalah kemudian yang menetapkan pilihannya untuk hidup di bawah bayangbayang sufistik, dan kemudian melepaskan dirinya untuk menghindari hidup di bawah bayang-bayang nalar semata.

\section{Teori al-Hikmah}

Perkenalan AHM dengan dunia tasawuf bukan hanya sekedar teori saja, namun melalui praktik harian yang kontinu dengan menekuni tarekat Shädhiliyyah. Tarekat inilah yang pertama kali memperkenalkannya dengan dunia tasawuf. Menurut AHM, tasawuf adalah sebuah praktik dunia spiritual

${ }^{100}$ Ibid.

${ }^{101}$ Muhammad 'Ābid al-Jābirī, Bunyah al-'Aql al-'Arabī; Dirāsah Tạ̣lïliyyah Naqdiyyah li al-Nuzūm al-Ma'rifah fì al-Thaqäfah al-'Arabiyyah (Bayrūt: Markaz Dirāsah al-Wị̣dah al-'Arabiyyah, 1990), 530. 
yang bila mendekati pemahamannya melalui ilmu-ilmu modern, maka hakikat tasawuf tidak akan tercapai. Karena semua ilmuilmu tersebut hanya mengkonsentrasikan diri pada hal-hal yang kongkret. ${ }^{102}$

AHM menekankan pentingnya reformasi terhadap pemahaman tentang dunia tasawuf, terutama dalam bentuk ritualnya (tarekat). AHM seperti yang dikatakan oleh Elizabeth Sirriyyeh, melihat tarekat-tarekat terutama di Mesir, mengalami kemunduran, kalau tidak dikatakan mengalami penyelewengan. Karena itu, ia menganjurkan untuk kembali kepada sumbersumber klasik agar dapat menemukan kembali bentuk sufisme yang otentik dan benar yang menekankan pada tanggung jawab sosial dan hidup dalam ketaatan kepada syariat. ${ }^{103}$

Menurut AHM, ilmu psikologi dan sosiologi modern gagal untuk mampu menyingkap dunia tasawuf dengan sebenarnya. Hal ini karena dunia tasawuf adalah suatu ilmu yang berkaitan dengan rūh, ilham dan isyrāq (pencerahan hati). Sebagian filosof yang rasionalis berusaha memahami tasawuf dari pendekatan rasional murni mereka menyangka bahwa kedalaman dan kekuatan berpikir mereka akan mampu menyingkap dunia spiritual dengan tepat. Namun fakta membuktikan bahwa akalpun tidak mampu untuk menyingkap dunia tasawuf secara tepat dan proporsional. AHM menyatakan, "Akal telah gagal menciptakan barometer benar dan salah dalam dunia roh (spiritual), juga gagal menciptakan penentu bagi kebenaran dan kebatilan dalam hal-hal yang gaib. Metode Aristoteles, Descrates dan semua metode rasional filsafat telah gagal total dan tidak mampu mengantarkan kita ke alam ketuhanan". ${ }^{104}$

Menurut AHM, harus dilakukan dekonstruksi ulang terhadap pembahasan-pembahasan dalam filsafat dan ilmu kalam (teologis) yang banyak melakukan pendekatan rasional. ${ }^{105}$ Akal, dalam pandangannya, tidak mampu menjadi barometer kebenaran dalam masalah-masalah yang terkait dengan alam gaib

${ }^{102}$ Mahmud, Qadiyyah al-Tasawwuf..., 189.

103Sirriyeh, Sufis and Anti-Sufis,..., 224.

${ }^{104}$ Abdul Halim Mahmud, Qadiyyah al-Tașawnuf Madrasah al-Shādhiliyyah (Kairo: Dār al-Ma’ārif, 1988), 419-420.

105Lihat, Mahmud, Al-Islām wa al-'Aql..., 115. 
(metafisika), karena hal itu bukanlah merupakan wewenang akal. Menurutnya, sejarah telah membuktikan bahwa pendekatan rasional tidak dapat memberikan keyakinan atau kepastian, bahkan cenderung bersifat żaniyyah (ragu-ragu). Karena itu, jika permasalahan metafisika di dekati dengan akal, maka ia akan tetap bersifat zaniyyah dan debatable. Disamping itu, perdebatanperdebatan ini tidak akan pernah berakhir, bahkan cenderung berpotensi memecah belah kesatuan umat. ${ }^{106}$

Namun demikan, kritik AHM terhadap akal, tidak serta merta menjadikannya sebagai seorang yang menafikan peran dan fungsi akal dalam kehidupan manusia. Ia menyadari peran akal sangat besar dalam membangun peradaban manusia, terutama yang terkait dengan peradaban materialistis yang secara keseluruhan merupakan kerja akal. ${ }^{107}$ Dalam permasalahan metafisika, akal tidak dapat menjangkau pengetahuan tentang Tuhan, karena pengetahuan tentang Tuhan hanya dapat diketahui melalui wahyu, dengan suatu cara yang ia sebut dengan irtiyaạ (olah rasa), yaitu usaha yang kontinu dalam mendekatkan diri kepada Tuhan dengan memperbanyak ibadah hingga akan terbuka bijäb (penghalang) baginya. 108

Dengan dasar ini, dan dalam rangka mencari hubungan antara filsafat yang bersifat teoretis dan tasawuf yang bersifat praktis kemudian lahirlah teorinya tentang al-hikmah. AHM menyatakan bahwa akal (filsafat) dapat juga mencapai al-hikmah yang dalam pandangan AHM adalah pengetahuan tentang Tuhan, walaupun tidak sempurna, karena filsafat menurut AHM bukan hanya sekedar teori, namun juga praktik (irtiya d. ). Dengan demikian, filsafat dalam pandangan AHM adalah pengantar menuju al-hikmah yang berkenaan dengan akal ('aql) dan praktik (irtiyāed). 109

\section{Catatan Akhir}

Sebelum membangun landasan-landasan epistemologisnya, AHM berusaha dengan keras memaparkan kelemahan-

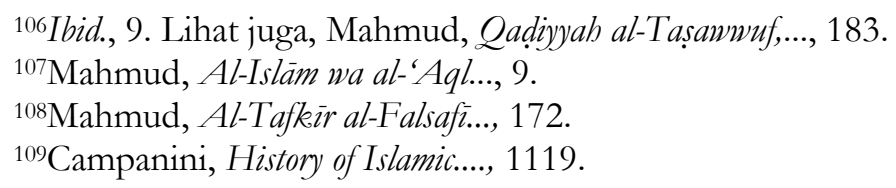


kelemahan indera dan akal. Menurut AHM, indera dan akal tidak dapat dijadikan sebagai barometer kebenaran, terutama mengenai hal-hal yang terkait dengan permasalahan metafisika (mà warà' al-tabìah). Indera dan akal hanya mampu mempersepsikan hal-hal yang bersifat materi dan inderawi (mahsūsah). Karena pengetahuan akal bersifat spekulatif, maka ia hanya dapat memberikan kebenaran nisbi dan temporal.

AHM membuat klasifikasi khusus tentang al-hikmah, di mana bikmah merupakan sintesa dari apa yang ia sebut dengan filsafat 'amaliyah (praktis) dan filsafat nazariyah (teoretis). Hikmah yang ia sebut sebagai ma'rifatullah tidak lain adalah hasil dari olah akal dan olah rasa. Beliau menyatakan, bahwa bikmah adalah ma'rifatullah sedangkan jalannya adalah filsafat. Filsafat menurutnya tidak hanya terbatas pada hal-hal yang bersifat teoretis, namun ia juga mencakup hal-hal yang bersifat praktis. Namun demikian, filsafat praktis atau yang ia sebut dengan irtiyạd lebih utama dari filsafat teoretis. Wa al-Läh a lam bi alsawāb.

\section{Daftar Pustaka}

Abrahamov, Benyamin. 2002. Theology; Tradisionalism and Rationalism, alih bahasa oleh; Nuruddin Hidayat, Imu Kalam; Tradisionalisme dan Rasionalisme dalam Teologi Islam. Jakarta: Serambi Ilmu Semesta.

'Abd al-Rāziq, 'Alī. tt. Islām wa Ușul al-Hukm. Kairo: al-Hay'āh al-'Āmmah li al-Kitāb.

Amīn, Aḥmad. 1969. Zuhr al-Islām. Beirūt: Dār al-Kitāb al'Arabī.

Arberry, A.J. tt. Revelation and Reason in Islam. London: Allen and Unwin. . 1950. Sufism; An Account of the Mystic of Islam. London: George Allen and Unwin.

Arkoun, Muḥammad. 1990. Al-Islām: al-Akhlāq wa al-Siyāsah, alih bahasa oleh Hishām Șāliḥ.Beirūt: Markaz al-Inmā’ al-Qawmī. . 1986. Tärikh al-Fiker al-'Arabi al-Islämì. Beirūt:

Markaz Inmā' al-Qawmī. 
Bas, Natana J. Delong. 2004. Wababi Islam from Revival and Reform to Global Jibad. London: Oxford University Press.

Campanini, Massimo. 1996. Islamic Philosophy in the Modern Islamic World (Egypt) dalam History of Islamic Philosophy, ed. Seyyed Hossein Nasr and Oliver Leaman. London: Routledge.

Cantwell Smith, Wilfred. 1957. Islam in Modern History. New Jersy: Princeton University Press.

Hilāl, Ibrāhīm. 1979. al-Tașawwuf al-Islāmì Bayn al-Dìn wa alFalsafah. Kairo: Dār al-Nahḍah al-'Arabiyyah.

Hourani, Albert. 1933. Arabic Thought in the Liberal Age 17981939. London: Oxford University Press.

'Imārah, Muḥammad. 1973. al-A'māl al-Kāmilāt li Mụ̣ammad 'Abduh. Beirūt: al-Mu'assasah al-'Arabiyyah li al-Dirāsāt wa al-Nashr.

Kartanegara, Mulyadi. 2003. Menyibak Tirai Kejabilan; Pengantar Epistemologi Islam. Bandung: Penerbit Mizan.

Lapidus, Ira M.. 2002. A History of Islamic Societies. Cambridge: Cambridge University Press, second edition.

Leaman, Oliver. 2001. Pengantar Filsafat Islam; Sebuah Pendekatan Tematis, alih bahasa oleh Musa Kazhim dan Arif Mulyadi. Bandung: Mizan.

Madkūr, Ibrāhīm. tt. Fì al-Falsafah al-Islāmiyyah Manhajubu wa Tațiqubu. Kairo: Dār al-Ma'ārif.

Maḥmūd, Abdul Halīm. 1997. Qadiyyah al-Tașawnuf al-Munqidh min al Ḍalāl. Kairo: Dār al-Ma’ārif. . 1978. Hāzihi Hayātì. Kairo: Dār al-Ma’ārif.

1988. Qadiyyah al-Tasawwuf Madrasah alSā̃iliyyah. Kairo: Dār al-Ma’ārif. . 1988. al-Islām wa al-'Aql. Kairo: Dār al-Ma’ārif.

Ma’ārif. . 1989. al-Tafkìr al-Falsafí fi al-Islām. Kairo: Dār al-

Muhammad Aḥmad, 'Abd al-'Ālī. 1978. al-Fiker al-Siyāsī li al-Imām Muhammad 'Abduh. Kairo: al-Hay'āh al-Mișriyyah li al-Kitāb.

Nasution, Harun. 1986. Teologi Islam Aliran-aliran Sejarah Analisa Perbandingan. Jakarta: UI Press.

Press. . 1986. Wabyu dan Akal dalam Islam. Jakarta: UI 
. 1987. Mubammad Abdub dan Teologi Rasional Mu'tazilah. Jakarta: UI Press.

Nusaibah, Sari. 1996. Epistemologi dalam, History of Islamic Philosophy, ed. Seyyed Hossein Nasr and Oliver Leaman. London: Routledge.

Rahman, Fazlur. 1984. Islam \& Modernity; Transformation an Intellectual Tradition. Chicago: The University of Chicago. . 1976. Some Islamic Issue In the Ayub Khan Era, dalam Essays on Islamic Civilization, ed. Donald P. Little. Leiden: E.J Brill.

Rahnema, Ali (ed.). 1996. Pioneers of Islamic Revival, alih bahasa oleh Ilyas Hasan Para Perintis Zaman Baru Islam. Bandung: Penerbit Mizan.

Rushd, Ibn. tt. Fașl al-Maqāl fì mā Bayn al-Hikmah wa al-Sharīah min al-Ittisāl. Kairo: Dār al-Ma'ārif.

Shimogaki, Kazuko. 1993. Kiri Islam antara Modernisme dan Postmodernisme; Telaah Kritis Pemikiran Hasan $\underline{H}$ anafi, alih bahasa oleh M. Imam Aziz dan M. Jadul Maula. Yogyakarta: LKiS.

Shahrūr, Muḥammad. 1993. al-Kitāb wa al-Qur'ān; Qiräah Mu'assirah. Kairo: Ibn Sīnā li al-Nashr.

Sirriyeh, Elizabeth. 2003. Sufis and Anti-Sufis, alih bahasa oleh Ade Alimah, Sufi dan Anti-Sufi. Jogyakarta: Penerbit Pustaka Sufi.

Schimmel, Annemarie. 2000. Mystical Dimension of Islam, ter. Supardi Djoko Purnomo, et.al., Dimensi Mistik dalam Islam. Jakarta: Penerbit Pustaka Firdaus.

Schleifer, Abdullah. 2003. Tasawuf di Mesir dan Timur Arab dalam Ensiklopedi Tematis Spiritual Islam Manifestasi, ed. Seyyed Hossien Nasr, ter. M. Solihin Arianto, et.al. Bandung: Penerbit Mizan.

Shalabī, Ra'ūf. 1983. al-Imām al-Akbar Shekh al-Islām 'Abd alHalìm Mạ̣mūd. Kuwait: Dār al-Qalam. 